\title{
Investigation of Foaming During Nuclear Defense- Waste Solidification by Electric Melting
}

H. T. Blair

J. M. Lukacs

December 1980

Prepared for the U.S. Department of Energy under Contract DE-AC06-76RLO 1830

Pacific Northwest Laboratory Operated for the U.S. Department of Energy by Battelle Memorial Institute 
NOTICE

This report was prepared as an account of work sponsored by the United States Government. Veither the United States nor the Department of Energy. nor any of their employees, nor any of their contractors, subcontractors. or their employees, makes any warranty, express or implied, or assumes any legal liability or responsibility for the accuracy. completeness or useiulness of any iniormation. apparatus, product or process disclosed, or represents that its use would not infringe privately owned rights.

The views. opinions and conclusions contained in this report are those of the contractor and do not necessarilv represent those of the United States Government or the United States Department of Energy.

\author{
PACIFIC NORTHWEST LABORATORY \\ operated by \\ BATTELLE \\ lor the \\ UNITED STATES DEPARTMENT OF ENERGY \\ Under Contract DE-AC06-76RLO 1830
}
Printed in the United States of America
Avaliable tram
Vational Technical tnformation Service
Unired States Department of Commerce
5285 Port Roval Road
Springtield. Virginia 22151

Price: Printed Copr 5

- Microfiche $\$ 3.00$

$\begin{array}{cc}\text {-Pages } & \begin{array}{c}\text { NTIS } \\ \text { Seiling Price }\end{array} \\ 001-025 & 54.00 \\ 026-050 & 54.50 \\ 051-075 & \$ 5.25 \\ 076-100 & 56.00 \\ 101-125 & 56.50 \\ 126-150 & 57.25 \\ 151-175 & 58.00 \\ 176-200 & \$ 9.00 \\ 201-225 & 59.25 \\ 226-250 & 59.50 \\ 251-275 & 510.75 \\ 276-300 & 511.00\end{array}$




\section{7}

INVESTIGATION OF FOAMING DURING NUCLEAR DEFENSEWASTE SOLIDIFICATION BY ELECTRIC MELTING

H. T. Blair

J. M. Lukacs

December 1980

Prepared for

the U.S. Department of Energy

under Contract DE-AC06-76RLO 1830

Pacific Northwest Laboratory

Richland, Washington 99352 
7

it 


\section{SUMMARY AND CONCLUSIONS}

The Pacific Northwest Laboratory (PNL), operated for the Department of Energy by Battelle Memorial Institute, has been developing equipment and processes for the solidification of high-level nuclear waste for many years. Conversion of the waste to a borosilicate glass in an electric melter is one of the processes with good prospects. However, when a waste composition simulating the nuclear defense waste stored at the Savannah River Plant was processed in a demonstration electric melter at PNL, the sustained capacity of the melter was on $1 y 30 \%$ of what it had been with other waste compositions. This reduction in melter capacity was due to the fact that the defense-waste composition tended to foam as it melted. The foam not only reduced the capacity of the melter, but the unpredictable nature of the foaming compromised control of the solidification process. Therefore, studies were done to determine the cause of the foaming and to develop methods of minimizing foaming. The goal was to increase the capacity of the melter and to improve process control.

To determine the cause of foaming, we investigated the physical and chemical composition of the glass formers that are added to the waste to produce a borosilicate melt. It was determined that the glass-forming frit was not the source of the foam-causing gases. Incomplete calcination of the waste, which results in residual hydrates, carbonates and nitrates, and the relatively high carbon and sulfate contents of the waste glass composition were also eliminated as possible sources of the foam. It was finally shown that the oxides of the multivalent ions of manganese and iron that are in the defense waste in high concentrations are the source of the foaming. Nickel oxide is also present in the waste and is suspected of contributing to the foaming.

In our investigation of methods to reduce the foam, we focused on the chemistry of the materials being processed rather than on the mechanical aspects of the processing equipment because we wanted to avoid increasing the mechanical complexity of the melter operation. The following procedures were tested: 
- reducing the waste loading in the host glass

- adding various reducing or fining (bubble removal) agents to the material to be melted

- controlling the atmosphere in the melter

- attempting to reduce the multivalent ions to their lowest oxidation states during the waste-calcining process.

Reducing the waste loading in the host glass from 28 to 14 wt\% produced the most significant reduction in the foam. Of course this did not increase the rate at which waste can be processed. Adding carbonaceous additives or barium metaphosphate to the waste/frit mixture (batch) reduced the foaming somewhat. However, if too much reducing agent was added to the batch, ironnickel alloys separated from the melt. Likewise, melting the batch in an inert or a reducing atmosphere reduced the foaming but produced a heterogeneous product. Finally, initial attempts to control foaming by adding reducing agents to the liquid waste and then spray-calcining it using an inert atomizing gas were not successful. The possibilities for liquid-waste treatment need to be investigated further.

In addition to the tests mentioned above, the performance of the various electric glass melters at PNL was briefly evaluated. The findings suggest that the stability and capacity of a melter is a function of the melt depth relative to the melt surface area. This relationship should be evaluated further using controlled tests.

The expected capacities of the electric melters have not yet been achieved when processing defense wastes. However, the studies described in this report have increased our understanding of foaming and offer assurance that foaming can be controlled and the desired melting rates achieved. 


\section{RECOMMENDATIONS}

Based on the experience and results achieved during these studies, the following recommendations are offered:

- The oxidation states of the multivalent ions of manganese, iron and nickel in the waste stored at the Savannah River facilities and in the liquid waste after it has been prepared according to the conceptual process flowsheet for solidification should be determined.

- The operating parameters of the spray calcination process, including the additives in the liquid feed, the nature of the atomizing gas or gases used, and the temperature of the calciner, should be studied to determine whether they can affect the oxidation states of the various components in the calcined waste.

- Additional and more complete multilevel factorial studies should be done to investigate the interactions of the various components in the batch and the relationship of these interactions to the melting behavior.

- The thermodynamics of the redox reactions of the multivalent ion oxides in the melt composition, as they occur in the electric melter, should be studied to see if metastable (oxygen supersaturation) conditions exist and what initiates nucleation. 


\section{ACKNOWLEDGMENTS}

The authors are indebted to G. L. Simpson and K. L. Tingey for their diligence in the laboratory performing the many tests required for this study. The analytical services of F. T. Hara and his staff are much appreciated. We thank F. A. Miller and G. N. Buck for performing the tests in the spray calciners. We also thank D. H. Parks for the optical ceramography and J. E. Coleman for the SEM and microprobe analyses. And we are very grateful to S. A. McCullough who edited the document. 
SUMMARY AND CONCLUSIONS

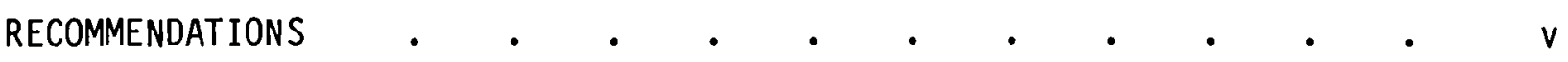

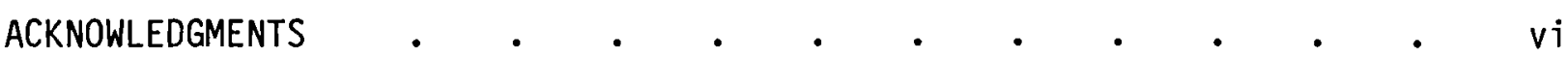

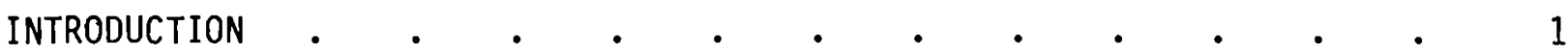

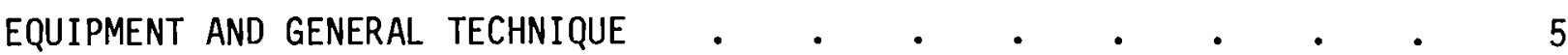

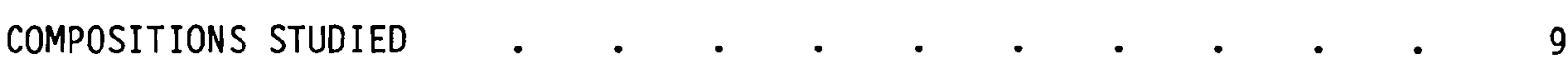

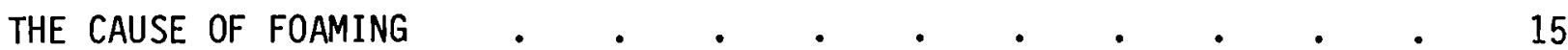

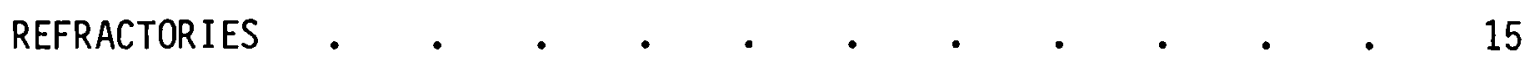

THE FRIT • • • • • • • • • • • • • • 15

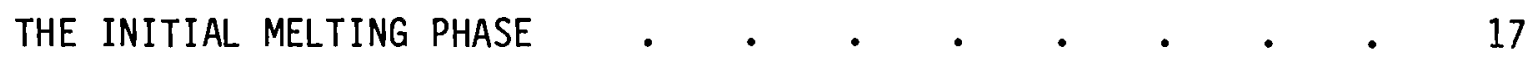

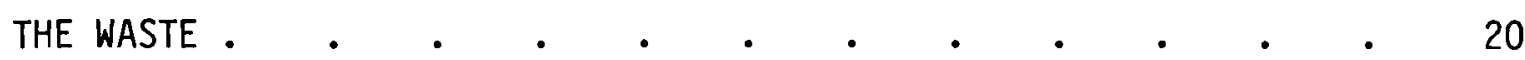

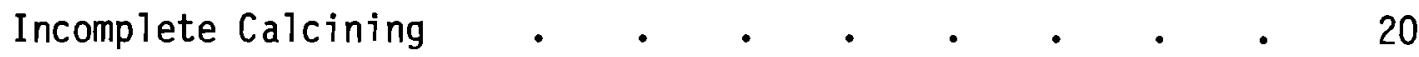

Carbon and Sodium Sulfate $\quad$. $\quad$. $\quad$. $\quad 20$

Oxidation States of Multivalent Ions . . . . . 22

EVALUATION OF METHODS TO REDUCE FOAMING • • • • • • • • • $\quad$ • 25

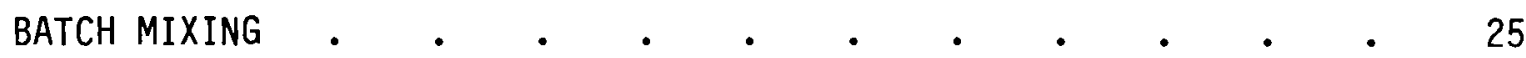

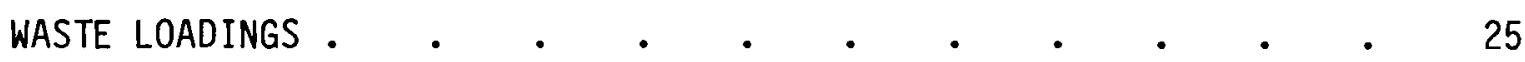

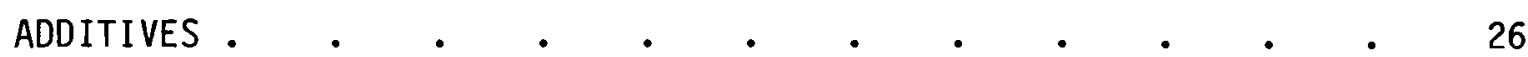

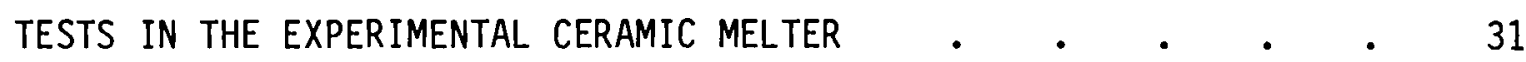

ATMOSPHERE CONTROL $\quad$ • . . . . . . . . . . . . . 33

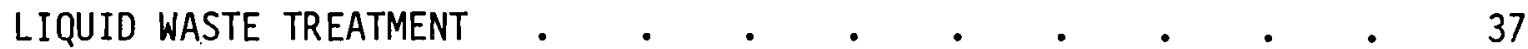

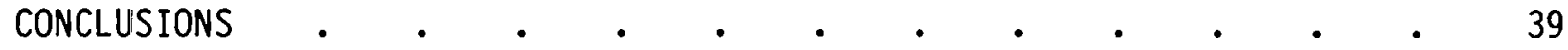

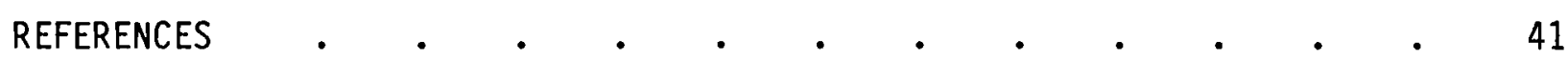

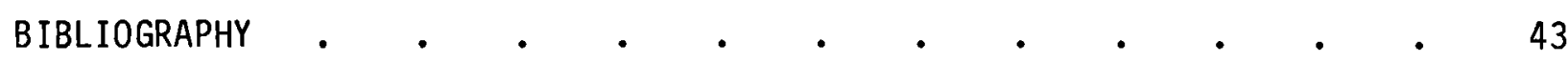

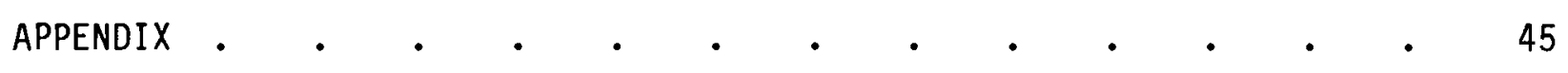




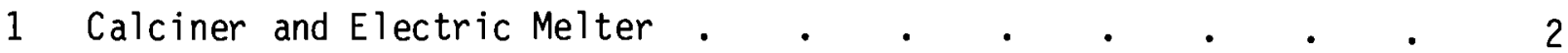

2 Foam Heights of a Defense-Waste Melt (Right) and a Soda-L ime Glass Melt (Left)

3 Experimental Ceramic Melter

4 Temperature Profiles in Experimental Ceramic Melter During Melt Foaming Studies

5 Photomicrographs of 28-wt\% Simulated TDS-2 Calcine/72-wt\% Frit

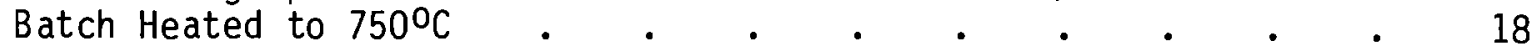

6 Photomicrographs of 28-wt\% Simulated TDS-2 Calcine/72-wt\% Frit Batch Heated to $800^{\circ} \mathrm{C}$

7 Foam Heights as a Function of Carbon and $\mathrm{Na}_{2} \mathrm{SO}_{4}$ Contents $\quad 22$

8 Carbohydrate Weight Loss Versus Temperature . . . . . 28

9 Effects of Different Atmospheres on Product Quality . . . . 36

A.1 X-ray Spectrum Trace of Particle-Free Matrix in Sample Held at

A.2 X-ray Spectrum Trace of Second Matrix Phase in Sample Held at $675^{\circ} \mathrm{C}$

A.3 X-ray Spectrum Trace of Continuous Matrix in Sample Held at $700^{\circ} \mathrm{C}$

A.4 X-ray Spectrum Trace of Second Matrix Phase in Sample Held at $700^{\circ} \mathrm{C}$

A.5 X-ray Spectrum Trace of Continuous Matrix in Sample Held at $750^{\circ} \mathrm{C}$

A.6 X-ray Spectrum Trace of Second Matrix Phase in Sample Held at $750^{\circ} \mathrm{C}$

A.7 X-ray Spectrum Trace of Large Particles in Sample Held at $750^{\circ} \mathrm{C}$

A.8 X-ray Spectrum Trace of Continuous Matrix in Sample Held at $800^{\circ} \mathrm{C}$

A.9 X-ray Spectrum Trace of Second Matrix Phase in Sample Held at $800^{\circ} \mathrm{C}$ 


\section{TABLES}

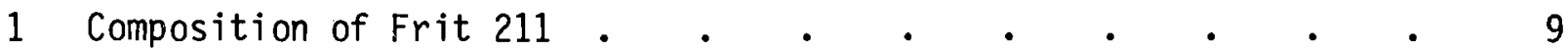

2 Compositions of Simulated SRP Wastes Used in The Melt

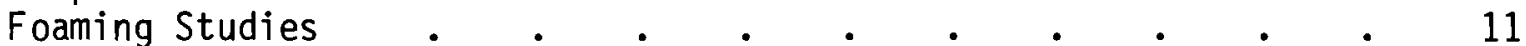

3 Composition of Linde Ionsiv-IE-95 Zeolite . . . . . 12

4 Assumed Composition of Batch Prepared by Combining

28-wt\% TDS-2 Waste with 72-wt\% Frit . . . . . . 13

5 Constituents Used to Prepare Each Glass Former . . . . 16

6 Carbon and Sodium Sulfate Concentrations Evaluated and the

Resulting Foam Heights . . . . . . . . . . 21

7 The Effects of Substitutions Made in the Preparation of

Simulated TDS Waste Calcine on Foam Height and Product Quality $\quad 23$

8 Results of Investigation to Determine Effects of Various

Components in TDS-2 Waste on Foam Height and Product Quality $\quad 24$

9 Effects of Simulated-Waste Loadings on Foam Heights and

Product Quality

10 The Effects on Foam Height of Adding Reducing Agents to SRP-13 Batch

11 The Effects of Additives on Foam Height and Product Quality . 29

12 Melter Tank Dimensions and Melting Rates . . . . . 32

13 Results of Contained Atmosphere Tests .

14 Foam Heights of Selected SRP Batches Melted in Various

Atmospheres

15 Response of $\mathrm{MnO}_{2}$ to Temperature and Atmosphere Changes When Exposed for One Hour. 


\section{INTRODUCTION}

For some years now the Pacific Northwest Laboratory (PNL), which is operated for the Department of Energy by Battelle Memorial Institute, has been designing, constructing and operating equipment for the solidification of nuclear wastes. One of the most promising pieces of equipment being developed is the electric melter, such as the unit shown in Figure 1. Because the power supplied to this melter is dissipated directly into the melt by passing a current through it between two electrodes, this type of melter should have a high processing capacity relative to its size. In fact, at PNL melting rates as high as $173 \mathrm{~kg} / \mathrm{h}$ have been demonstrated in an electric melter that has a melting surface area of $1.05 \mathrm{~m}^{2}\left(2.5 \mathrm{ft}^{2} /\right.$ ton/d) (Chapman 1979). However, when a waste composition simulating the nuclear defense waste stored at the Savannah River Plant (SRP) was mixed with specially formulated glass-forming frit and processed in this same melter, the maximum sustained melting rate was $51 \mathrm{~kg} / \mathrm{h}$ $\left(8.4 \mathrm{ft}^{2} /\right.$ ton/day). This severe reduction in melter capacity was caused by the tendency of the SRP composition to foam as it melted (McElroy 1979). An even more serious concern than the effect of foaming on the melting rate was the unpredictable nature of the foaming, which hampered the control of the waste vitrification process. Stable melter operation could be maintained for various periods ranging from 1 to $8 \mathrm{~h}$. Then, for no apparent reason, vigorous gas evolution would suddenly fill the melter with foam and would occasionally displace unmelted batch and foam through the melter throat into the receiving container. The purpose of the studies reported here was to develop wasteprocessing procedures that would minimize foaming and its effect on the melting rate and on the control of the melting process.

The literature indicates that such factors as 1) melt viscosity and surface tension, 2) gas solubility in the melt, and 3) bubble nucleation sites are important to the evolution and persistence of molten-glass foaming in melters. The composition of the glass has also been reported to be an important factor. For example, foaming is often associated with the decomposition of nitrates, carbonates, or hydrates in the batch materials charged to the melter to make glass. Sodium sulfate and carbon, which result in supersaturation 


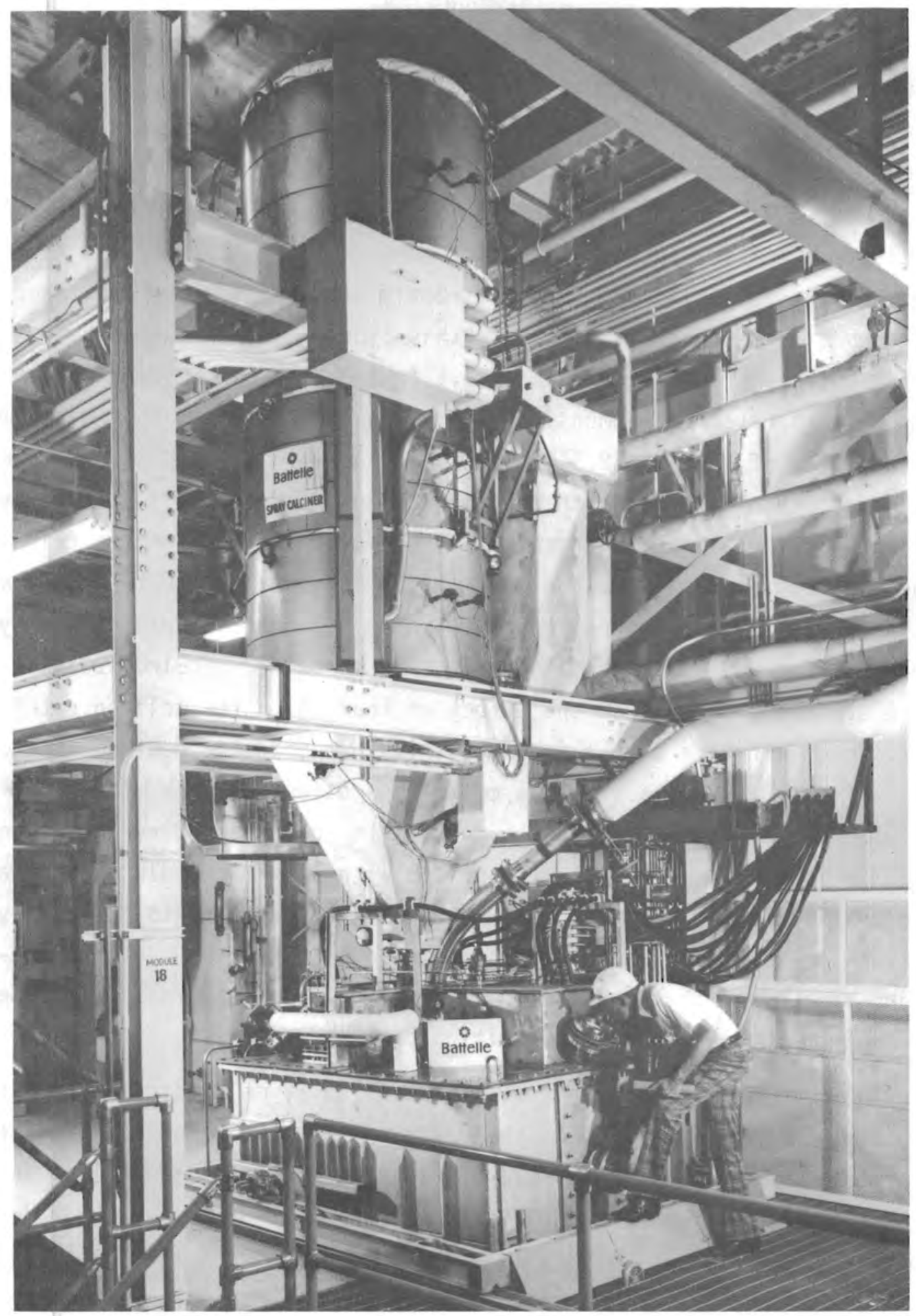

FIGURE 1. Calciner and Electric Melter 
of $\mathrm{SO}_{3}$ in the melt, are the usual cause of foaming or reboiling in refined (bubble-free) glass. Melt foaming can also occur in melts containing sulfate when the oxidation state of the glass is altered by a changeover in the tank between flint and amber glasses. Reboil of glass melts has also been associated with the redox phenomenon where oxygen is the only gas released.

While the foaming studies described in the literature are valid for the soda-lime compositions studied, there was at the outset of this investigation considerable uncertainty as to whether they would be applicable to defensewaste glass compositions. This is because soda-lime glasses contain very little iron, manganese and nickel, while the simulated defense-waste glass composition causing the foaming problems is a borosilicate glass containing more than 14 wt\% iron oxide, nearly 4 wt\% manganese oxide and 2 wt\% nickel oxide. Its sodium sulfate content is nearly double the limits published for soda-lime batch.

The literature on soda-lime compositions did suggest several approaches to foam control or prevention. One approach would be to facilitate the release of the gas from the melt by altering the batch composition to reduce melt viscosity and surface tension. However, this approach would not be practical because a viscous layer would always be present between the melt and the unmelted batch deposited on the melt surface (the cold cap) to reduce the loss of heat and volatiles. Another approach would be to change the melter configuration to decrease the distance gas must rise through the melt to the surface or to use sonics, centrifugal force, stirrers or bubblers to aid gas removal from the melt. However, this approach would only complicate melter design and remote operation. A third approach would be to find a fining agent that could be added to the batch that would increase the solubility of the gas in the melt. Finally, a fourth approach would be to to alter the chemistry of the batch so that the gases would be released from the batch before it was melted. This could be accomplished by controlling the oxygen partial pressure within the melter or by pretreating of the waste and/or frit before they are charged to the melter. The emphasis was placed on the latter two approaches in these studies because they would not require major equipment or operating modifications. 
Many different avenues were explored in the search for the causes of the foaming and for processing steps to control it. So that others involved in similar studies will have the full benefit of our experience, this report discusses all areas investigated, those that were unfruitful as well as those that lead to useful results. 


\section{EQUIPMENT AND GENERAL TECHNIQUE}

Because the purpose of this study was to identify processing steps that could be applied in the full-scale melters, the laboratory techniques used were more of a qualitative than of a quantitative nature. The major emphas is was placed on relative results. Batch samples were prepared by mixing the various components without comminution. Sixteen- or $25 \mathrm{~g}$ s samples were placed in tared, 50-ml porcelain crucibles and were heated to the desired temperature in a resistance-heated laboratory furnace. The normal heating rate was $200^{\circ} \mathrm{C} / \mathrm{h}$, and the usual melting temperature was $1050^{\circ} \mathrm{C}$. As many as ten crucibles were heated at once in the furnace. They were supported on an Incone ${ }^{\circledR}$ tray that protected the furnace from spills and made it easier to remove the crucibles from the furnace to air-quench the melts. Because of the differences in the thermal expansions of the melts and crucibles, the crucibles were usually cracked or in pieces after cooling. Therefore, the samples were of ten removed from the furnace at the melt temperature and were placed in metal cans to aircool so that the pieces could be contained and weighed. An Inconel retort that permitted complete control of the atmosphere during melting was used in the furnace for some tests. However, use of the retort did not permit removal of the melts from the furnace for quenching from high temperatures.

The typical foam height in a crucible in which $25 \mathrm{~g}$ of defense-waste batch were melted is shown in Figure 2. The foam height of a soda-lime glass melt is also shown for comparison. The foam height was determined by measuring from the top of the crucible down to the ring left by the foam around the inside of the crucible. The high point, low point and an in-between point were measured to the nearest $0.4 \mathrm{~mm}(1 / 64 \mathrm{in.})$, and the three measurements were averaged and subtracted from the inside depth of the crucible. When the crucibles did not break during cooling, the foam volume was measured more precisely by filling the crucible with water up to the ring left by the foam and weighing the amount of water used. A detergent was added to the water to decrease the surface tension. All weights were taken to a milligram.

هHuntington Alloy Products Division of International Nickel Company, Inc. 


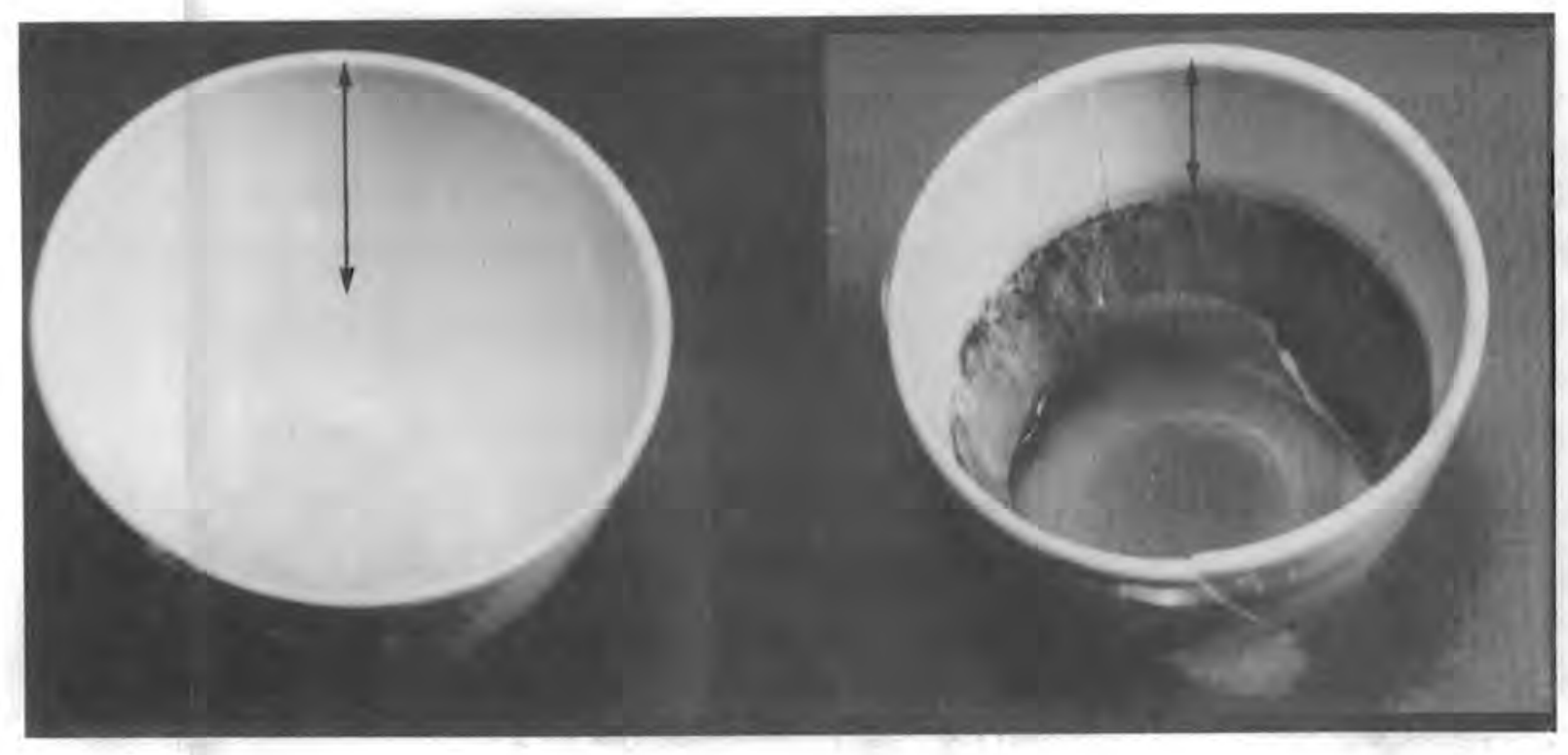

FIGURE 2. Foam Heights of a Defense-Waste Melt (Right) and a Soda-Lime Glass Melt (Left)

In addition to the melting tests performed in crucibles in the laboratory furnace, some melting tests were performed in the experimental ceramic melter (ECM) (MCElroy 1979). The ECM, shown in Figure 3, is a bench-scale electric glass-melting tank capable of processing $10 \mathrm{~kg}$ of batch per hour. Batches for these tests were prepared by placing the weighed components in a drum and mixing them on a barrel roller. The ECM was charged with $3 \mathrm{~kg}$ of blended batch every 20 min. Glass production was continuous with surges each time batch was added. A typical temperature profile of the contents of this melter is presented in Figure 4 . The me1t depth in the tank was about $140 \mathrm{~mm}$. 


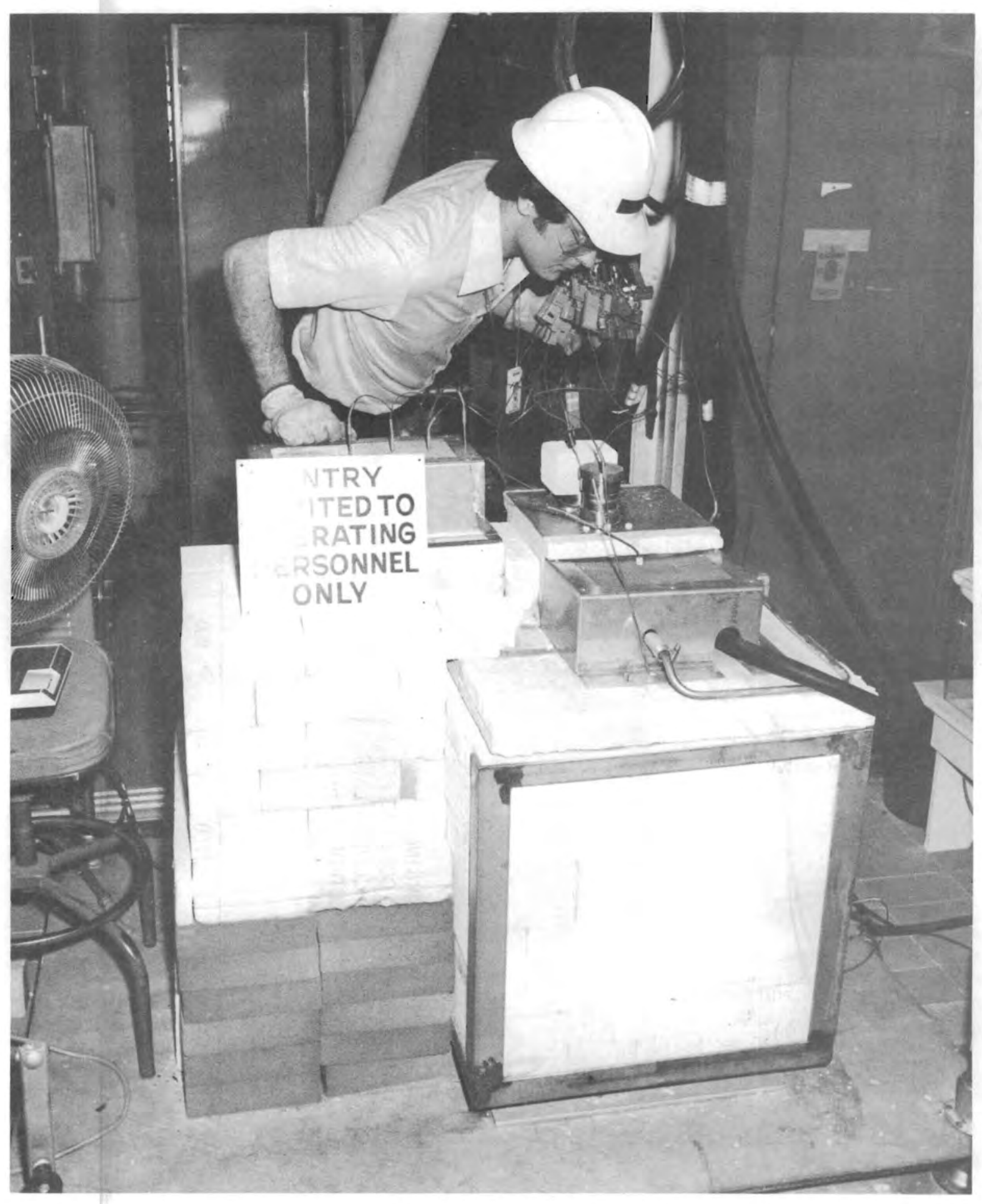

FIGURE 3. Experimental Ceramic Melter 


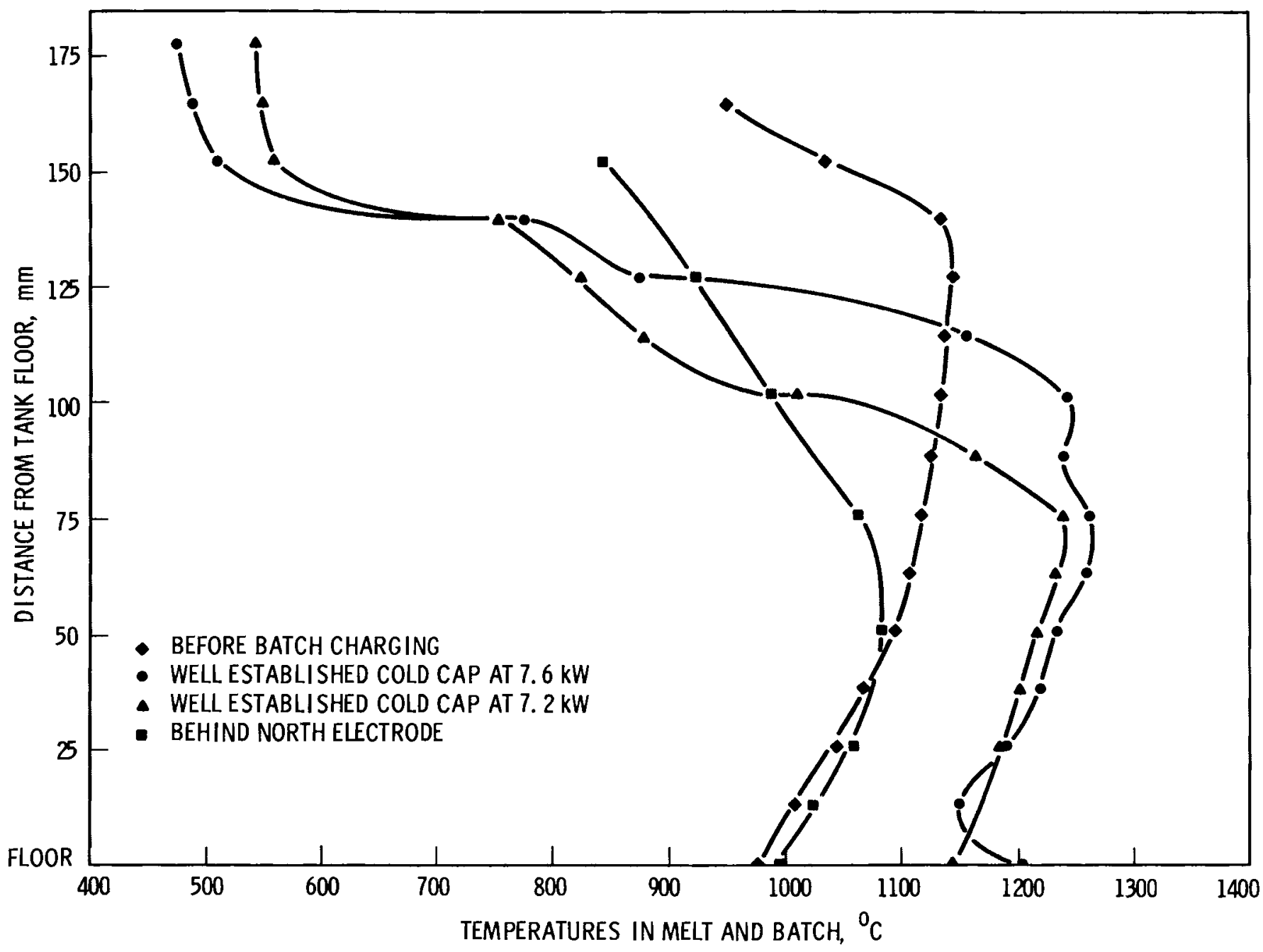

FIGURE 4. Temperature Profiles in the Experimental Ceramic Melter During Melt Foaming Studies 


\section{COMPOSITIONS STUDIED}

The glass-forming frit used in this study was Frit 211, which was developed at Savannah River Laboratory (SRL). The frit composition is presented in Table 1. The frit was usually sized -20 mesh $/ 80$ mesh unless otherwise indicated. The frit and simulated waste were blended in proportions of 72 parts by weight frit to 28 parts by weight dry waste unless otherwise indicated.

The simulated-waste compositions used for this study were also provided by SRL. The compositions were formulated to simulate wastes (stored at the Savannah River facilities) after they have been prepared for solidification according to a conceptual flowsheet. More than one composition was used because as the development of waste processing has progressed, the conceptual flowsheet and thus the waste composition have also changed. Table 2 presents all the compositions used over the course of these studies.

The original composition used was designated TDS waste. A large batch was prepared using the TDS formula by drying an aqueous slurry in a commercial spray dryer. The resulting powder contained 30 -wt\% residual volatiles. This powder was mixed with Frit 211 in proportions of 28-wt\% powder to 72 -wt\% frit. This blend was designated SRP-13 and was used to conduct a 5-day demonstration in PNL's full-scale liquid-fed ceramic melter (LFCM) (Buelt 1979). The batch exhibited extreme foaming when melted so it was chosen as the reference batch for our foam-control studies. However, later the use of the SRP-13 batch was discontinued because of concern that spray drying at $250^{\circ} \mathrm{C}$ to $600^{\circ} \mathrm{C}$ produces a waste that is not typical of that specified by the conceptual flowsheet. The

TABLE 1. Composition of Frit 211

\begin{tabular}{lc} 
Component & Quantity, wt\% \\
\hline $\mathrm{SiO}_{2}$ & 58.3 \\
$\mathrm{Na}_{2} \mathrm{O}$ & 20.6 \\
$\mathrm{~B}_{2} \mathrm{O}_{3}$ & 11.1 \\
$\mathrm{CaO}$ & 5.6 \\
$\mathrm{Li}_{2} \mathrm{O}$ & 4.4
\end{tabular}


conceptual flowsheet specifies that a heated-wall spray calciner operated at $700^{\circ} \mathrm{C}$ to $800^{\circ} \mathrm{C}$ will be used. Therefore, since no simulated TDS liquid waste had been processed in a calciner at that time, simulated calcine was prepared by blending the components listed in Table 2. Still later a change in the conceptual flowsheet resulted in new waste compositions that were designated TDS-2 and TDS-3. The components used to simulate both the liquid and calcined forms of TDS-2 are also presented in Table 2. The TDS-3 composition is the same as the TDS-2 except the tetrasodium-EDTA is not included in the TDS -3 .

The TDS-2 waste composition was considered to be representative of the highest carbon content that might be expected in a waste stream. This composition contains 3.5 times more carbon than does the original composition with 1-wt\% cornstarch added. Therefore, in going from TDS to TDS-2 the glass chemistry changed from an oxidized glass to a reduced glass, and the precipitation of metals from the melt became a significant processing concern for an electric melter.

Table 2 also lists the compositions of two calcines, FSSC-37 and DSS-80-4, that were prepared from TDS-2 and TDS-3, respectively, in the heated-wall spray calciners at PNL. These calcines were used to perform some of the foaming tests. The FSSC-37 calcine, which was prepared in a full-scale calciner, contained only 66 wt\% of the $\mathrm{Fe}_{2} \mathrm{O}_{3}$ that it should, but the carbon content was 2-1/2 times greater than it should be and the sulfur content was almost double the desired amount. The chloride was in excess because the $\mathrm{Fe}(\mathrm{OH})_{3}$ solution used to prepare the simulated TDS-2 waste was contaminated with chlorine. (a) The DSS-80-4 calcine was prepared in a pilot-scale calciner. By eliminating the $\mathrm{Na}_{4}$ EDTA, the carbon content of this calcine was reduced from 4.6 to 1.9 wt\% and the equivalent $\mathrm{Na}_{2} \mathrm{O}$ content was reduced from 5.0 to 2.1 wt\%. Note that the oxides listed in Table 2 for FSSC-37 and DSS-80-4 are assumed and the weight percents do not total 100 . This is because the compositions of these

(a) During the production of FSSC-37 calcine, the calciner was coupled directly to an in-can melter and the calcine was melted with the frit. Flames were observed in the melter during the demonstration and metal nuggets were deposited at the bottom of the melt. This confirmed our concerns about this being a reducing batch composition resulting in metal deposition. 
TABLE 2. Compositions of Simulated SRP Wastes Used in The Melt Foaming Studies

\begin{tabular}{|c|c|c|c|c|c|c|c|c|}
\hline \multirow{2}{*}{\multicolumn{3}{|c|}{ Simulated Liquid Waste }} & \multirow{2}{*}{\multicolumn{3}{|c|}{ Simulated Calcine }} & \multicolumn{3}{|c|}{ Calcined Simulated Liquid Waste } \\
\hline & & & & & & $\begin{array}{l}\text { Assumed } \\
\text { Component }\end{array}$ & FSSC-37, wt\% & DSS-80-4, wt\% \\
\hline $\mathrm{Al}(\mathrm{OH})_{3}$ & 8.8 & 10.51 & $\mathrm{Al}_{2} \mathrm{O}_{3}$ & 11.2 & 9.7 & $\mathrm{Al}_{2} \mathrm{O}_{3}$ & 3.05 & 12.2 \\
\hline Anthracite & - & 1.74 & Anthracite & - & 2.4 & C & 3.8 & 1.09 \\
\hline $\mathrm{CaCO}_{3}$ & 3.2 & 3.82 & $\mathrm{CaCO}_{3}$ & - & 5.4 & $\mathrm{CaO}$ & 3.9 & 3.36 \\
\hline & & & $\mathrm{CaO}$ & 3.5 & - & & & \\
\hline Cornstarch & - & 0.342 & Cornstarch & - & 0.5 & & & \\
\hline $\mathrm{CsNO}_{3}$ & - & 0.040 & $\mathrm{CsCl}$ & - & 0.06 & & & \\
\hline $\mathrm{Fe}(\mathrm{OH})_{3}$ & 35.0 & 41.90 & $\mathrm{Fe}_{2} \mathrm{O}_{3}$ & 51.2 & 44.1 & $\mathrm{Fe}_{2} \mathrm{O}_{3}$ & 28.3 & 44.7 \\
\hline $\mathrm{MnO}_{2}$ & 7.0 & 8.36 & $\mathrm{MnO}_{2}$ & 13.7 & 11.7 & $\mathrm{MnO}_{2}$ & 13.0 & 10.2 \\
\hline $\mathrm{NaCl}$ & - & 0.983 & $\mathrm{NaCl}$ & - & 1.4 & Cl & 0.35 & 2.23 \\
\hline $\mathrm{Na}_{4}$ EDTA & - & 4.86 & $\mathrm{Na}_{4}$ EDTA & - & 6.9 & $\mathrm{Na}_{2} \mathrm{O}$ & 5.7 & 2.77 \\
\hline $\mathrm{NaF}$ & - & 0.100 & $\mathrm{NaF}$ & - & 0.2 & $F$ & 0.05 & 0.02 \\
\hline $\mathrm{NaNO}_{3}$ & 1.5 & 1.76 & $\mathrm{NaNO}_{3}$ & 2.8 & 2.5 & $\mathrm{NO}_{3}$ & - & 0.28 \\
\hline $\mathrm{Na}_{2} \mathrm{SO}_{4}$ & 0.7 & 0.859 & $\mathrm{Na}_{2} \mathrm{SO}_{4}$ & 1.4 & 1.2 & $S$ & 0.18 & 0.36 \\
\hline $\mathrm{NiO} \cdot 2 \mathrm{H}_{2} \mathrm{O}$ & 3.8 & 5.40 & NiO & 6.0 & 5.1 & NiO & 4.9 & 5.81 \\
\hline $\mathrm{Sr}\left(\mathrm{NO}_{3}\right)_{2}$ & - & 0.040 & sro & - & 0.06 & Sro & - & 0.06 \\
\hline Zeolite & 5.2 & 6.22 & Zeolite & 10.2 & 8.8 & $\mathrm{SiO}_{2}$ & 7.32 & 5.75 \\
\hline & & & & & & $\mathrm{B}_{2} \mathrm{O}_{3}$ & - & 0.11 \\
\hline & & & & & & LOI & 26.1 & 14.86 \\
\hline
\end{tabular}

(a) Weight Lost on Ignition at $800^{\circ} \mathrm{C}$. 
two calcines were determined by various analytical methods that only identify the element present and not the compound or oxidation state of the cations. Calcines produced in the heated-wall spray calciners contain residual nitrates, carbonates and sulfates. In addition, much of the anthracite, cornstarch, and $\mathrm{Na}_{4}$ EDTA pass through the calciner unaltered.

The anthracite coal and the cornstarch used in these studies were analyzed for total carbon content. The coal contained 65.4 -wt\% carbon and the cornstarch was 38.9-wt\% carbon. The carbon content of the tetrasodium-EDTA, $\mathrm{C}_{2} \mathrm{H}_{4} \mathrm{~N}_{2}\left(\mathrm{CH}_{2} \mathrm{COO}\right)_{4} \mathrm{Na}_{4}$, was calculated to be 31.6 wt\% and the carbon content of $\mathrm{CaCO}_{3}$ was $12 \mathrm{wt} \%$. The composition of the zeolite used is presented in Table 3.

By compiling the various compositional information presented, the total batch composition for a 28-wt\% TDS-2/72-wt\% frit blend would be that given in Table 4. This glass batch composition is unique because of the high carbon, iron, manganese, nickel and sulfate contents and the low silica content. Therefore, it was difficult to find any information on prior experience with the melting behavior of such a composition. Melts prepared from basalts appear to be the most similar (Beall and Hermann 1976).

TABLE 3. Composition of Linde Ionsiv-IE-95 ${ }^{\circledR}$ Zeolite

\begin{tabular}{lr} 
Oxide & Quantity, \\
\hline $\mathrm{Al}_{2} \mathrm{O}_{3}$ & 17.1 \\
$\mathrm{CaO}^{2}$ & 3.9 \\
$\mathrm{Fe}_{2} \mathrm{O}_{3}$ & 4.0 \\
$\mathrm{MnO}_{2}$ & 0.1 \\
$\mathrm{Na}_{2} \mathrm{O}$ & 4.4 \\
$\mathrm{SiO}_{2}$ & 68.6 \\
Other & 1.9
\end{tabular}

(-) inde Division of Union Carbide Corporation. 
TABLE 4. Assumed Composition of Batch Prepared by Combining 28-wt\% TDS-2 Waste with 72-wt\% Frit

$\begin{array}{lr}\text { Component } & \text { Quantity, wt\% } \\ \mathrm{Al}_{2} \mathrm{O}_{3} & 3.61 \\ \mathrm{~B}_{2} \mathrm{O}_{3} & 7.80 \\ \mathrm{C} & 1.25 \\ \mathrm{CaO} & 5.08 \\ \mathrm{Cl} & 0.21 \\ \mathrm{Cs}_{2} \mathrm{O} & 0.02 \\ \mathrm{~F} & 0.02 \\ \mathrm{Fe}_{2} \mathrm{O}_{3} & 14.35 \\ \mathrm{Li}_{2} \mathrm{O} & 3.12 \\ \mathrm{MnO}_{2} & 3.82 \\ \mathrm{Na}_{2} \mathrm{O} & 15.77 \\ \mathrm{NiO}^{0} & 1.66 \\ \mathrm{Na}_{2} \mathrm{SO}_{4} & 0.39 \\ \mathrm{SiO}_{2} & 42.89 \\ \mathrm{SrO}^{0} & 0.01\end{array}$



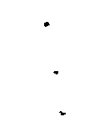


\section{THE CAUSE OF FOAMING}

Several possible sources of the foam-causing gas were investigated. The refractories used to line the melter and the frit were both investigated as possible nucleation sites for bubble formation. The chemical composition and water content of the glass formers were also studied to see what effect they had on foaming. The fusing of frit and waste-loaded glass was observed to see if the interaction of the two different glasses caused a change in oxygen or $\mathrm{SO}_{2}$ solubility. The glass-forming agents, whether in the form of a frit or simply as a blend of chemical compounds, do not appear to be the source of the foam-causing gas. However, the frit studied does have a low melting point relative to the temperature at which the gas is evolved and thus impedes the escape of the gas from the melting batch. The waste appears to be the source of the gas.

\section{REFRACTORIES}

Early in the study of the foaming phenomenon the possibility that the chromium oxide refractory used to line the melters was contributing to the foaming was evaluated. Three chips of Monofrax K-3 ${ }^{\otimes}$ refractory totaling $8 \mathrm{~g}$ were covered with $16 \mathrm{~g}$ of SRP -13 batch and heated to $1050^{\circ} \mathrm{C}$ in air. The results suggest that the presence of the chromium oxide refractory reduced the amount of foaming relative to that of the control melt. However, the reduction was not significant.

\section{THE FRIT}

A series of crucible melts was run to evaluate the impact of the glassformer formulation on foaming. Each batch contained 28-wt\% oxide of TDS calcine with 72-wt\% oxide of glass former. The glass-former constituents were added in five different forms: as 1) frit, 2) oxides, 3) hydroxides, 4) carbonates or 5) nitrates. Table 5 lists the chemical compounds in each form. Since the oxide composition of the resulting glass does not change when the

هThe Carborundum Company, Refractories Division. 
TABLE 5. Constituents Used to Prepare Each Glass Former

Glass Former

Constituents

Frit

(premelted and ground)

Oxide

$\mathrm{SiO}$

$\mathrm{B}_{2} \mathrm{O}_{3}$

$\mathrm{Na}_{2} \mathrm{SiO}_{3} \cdot 5 \mathrm{H}_{2} \mathrm{O}$

$\mathrm{Li}_{2} \mathrm{SiO}_{3}$

$\mathrm{CaO}$

Hydroxide

$\mathrm{SiO}_{2}$

$\mathrm{B}_{2} \mathrm{O}_{3} \quad \mathrm{NaOH}$

$\mathrm{LiOH}$

$\mathrm{Ca}(\mathrm{OH})_{2}$

Carbonate

$\mathrm{SiO}_{2}$

$\mathrm{B}_{2} \mathrm{O}_{3} \quad \mathrm{Na}_{2} \mathrm{CO}_{3}$

$\mathrm{Li}_{2} \mathrm{CO}_{3}$

$\mathrm{CaCO}_{3}$

Nitrate

$\mathrm{SiO}_{2} \quad \mathrm{~B}_{2} \mathrm{O}_{3} \quad \mathrm{NaNO}_{3}$

$\mathrm{LiNO}_{3}$

$\mathrm{Ca}\left(\mathrm{NO}_{3}\right)_{2}$

form changes, only the sequence of chemical reactions during melting was altered. Foaming was evaluated by melting at $800^{\circ} \mathrm{C}$. The relatively low temperature was used to maintain foaming and improve experimental sensitivity. Although the five different batches covered a broad range of melting points and weight losses, the calcine/frit combination, which has been used in most melter demonstrations, produced the lowest foam height. The other batches in order of increasing foam height were oxides, carbonates, hydroxides, and nitrates.

In a separate experiment, the frit was analyzed by $x$-ray diffraction to see if unreacted $\mathrm{SiO}_{2}$ crystallites were present to act as nucleation sites for bubble formation in the melt. No trace of silica crystals was detected in the frit samples. Additional analyses showed that frit stored outdoors in sealed barrels contained 0.25 -wt\% water. This moisture content did not cause foaming when the frit was melted.

Michell and Brungs (1976) reported that severe foaming occurs when the oxidation state of a glass composition changes (such as from flint to amber) substantially while being melted. To determine whether or not this occurs when frit and a melt loaded with defense waste are melted together, the following test was run. First, 42-wt\% simulated TDS calcine and 58-wt\% frit were melted together and cooled to prepare a defense-waste-loaded melt. Then this waste-loaded glass was crushed and $10 \mathrm{~g}$ were blended with $6 \mathrm{~g}$ of frit and melted at $1050^{\circ} \mathrm{C}$. While the first batch foamed excessively, there was no foaming when the waste-loaded glass was melted together with frit. This 
result suggests that foam is produced during the melting together of calcined SRP waste and frit rather than during any interaction of frit with a wasteloaded melt.

\section{THE INITIAL MELTING PHASE}

To determine the temperatures at which the batch begins to melt and at which the foaming occurs, batch samples (28-wt\% simulated TDS-2/72-wt\% frit) were heated for one hour at temperatures ranging from $500^{\circ} \mathrm{C}$ to $1100^{\circ} \mathrm{C}$ and were then quenched in air. The sample held at $600^{\circ} \mathrm{C}$ was still a free-flowing powder when cooled, while the one heated to $700^{\circ} \mathrm{C}$ was a fused clinker. A viscous, vitreous foam was produced by heating the batch to $800^{\circ} \mathrm{C}$. Heating to $900^{\circ} \mathrm{C}$ produced a black glass that did not contain any bubbles.

Additional samples were then prepared by heating at $675^{\circ} \mathrm{C}, 700^{\circ} \mathrm{C}, 750^{\circ} \mathrm{C}$ and $800^{\circ} \mathrm{C}$. These were mounted, polished and examined by optical and scanning electron microscopy to identify the components that were melting first and trapping the gases that were released. The microprobe traces are presented in the appendix. They show that the frit reacts with the iron oxide in the simulated calcined waste and melts first at about $675^{\circ} \mathrm{C}$ to fuse the batch together.

In the sample shown in Figure 5 , which was held at $750^{\circ} \mathrm{C}$, the melted frit has fused most of the batch together although much of the simulated calcine particles have not yet gone into solution. Small bubbles are just beginning to form in the melt. Many of them are associated with large, undissolved particles that the microprobe identified as a manganese compound. This can be seen clearly under $250 \mathrm{x}$ magnification in Figure 5.

At $800^{\circ} \mathrm{C}$ the frit had completely melted to form a continuous, viscous matrix and gas evolution had produced many large bubbles that were trapped in this matrix, as shown in Figure 6. Many particles that had not yet dissolved in the melt are still visible. Two prominent undissolved phases were identified with the microprobe to be a manganese compound and an aluminum-calcium compound. The probe analyses show that much of the sulfur, chlorine and iron had dissolved in the melted material. 


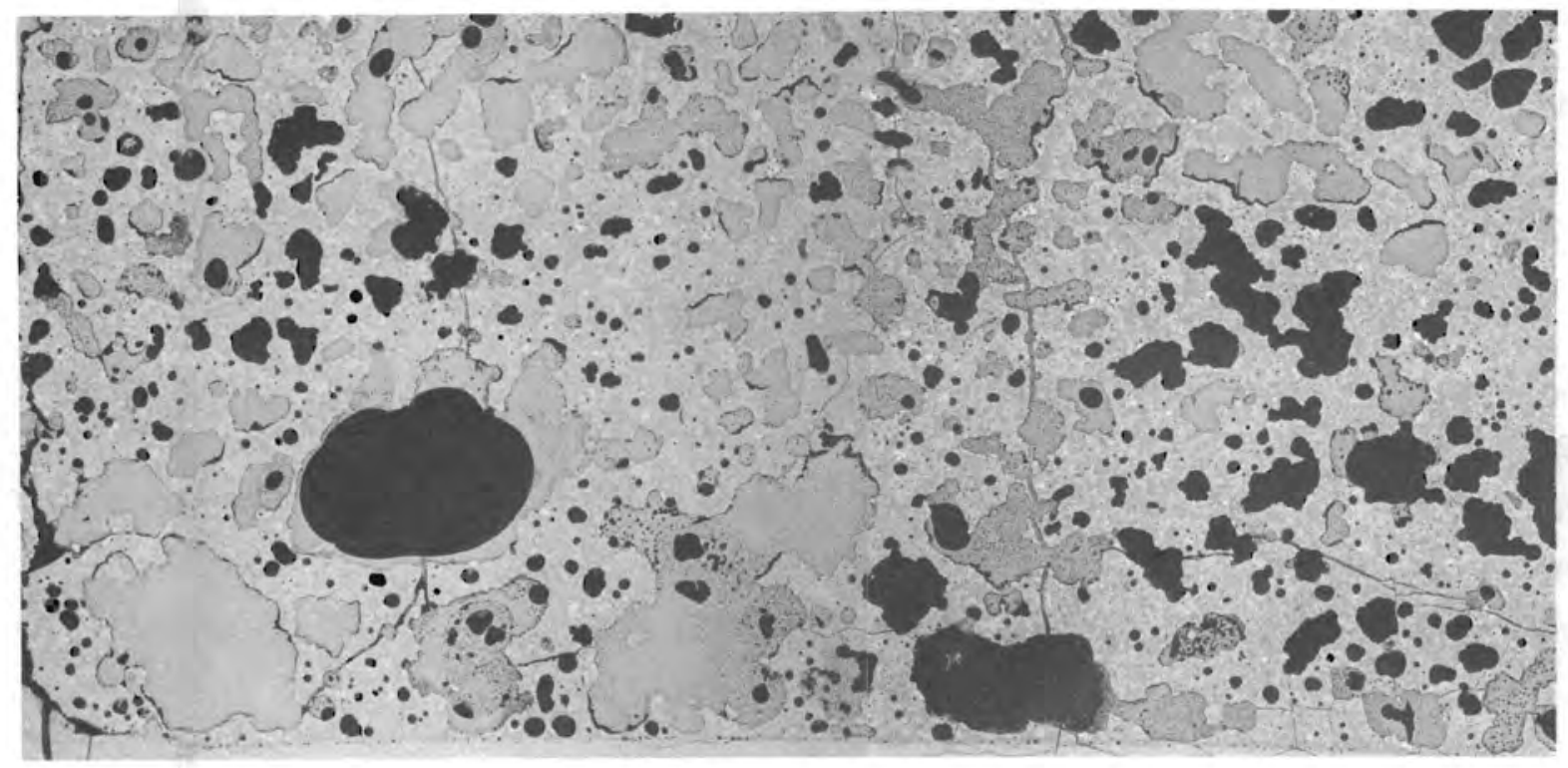

$8.9 x$
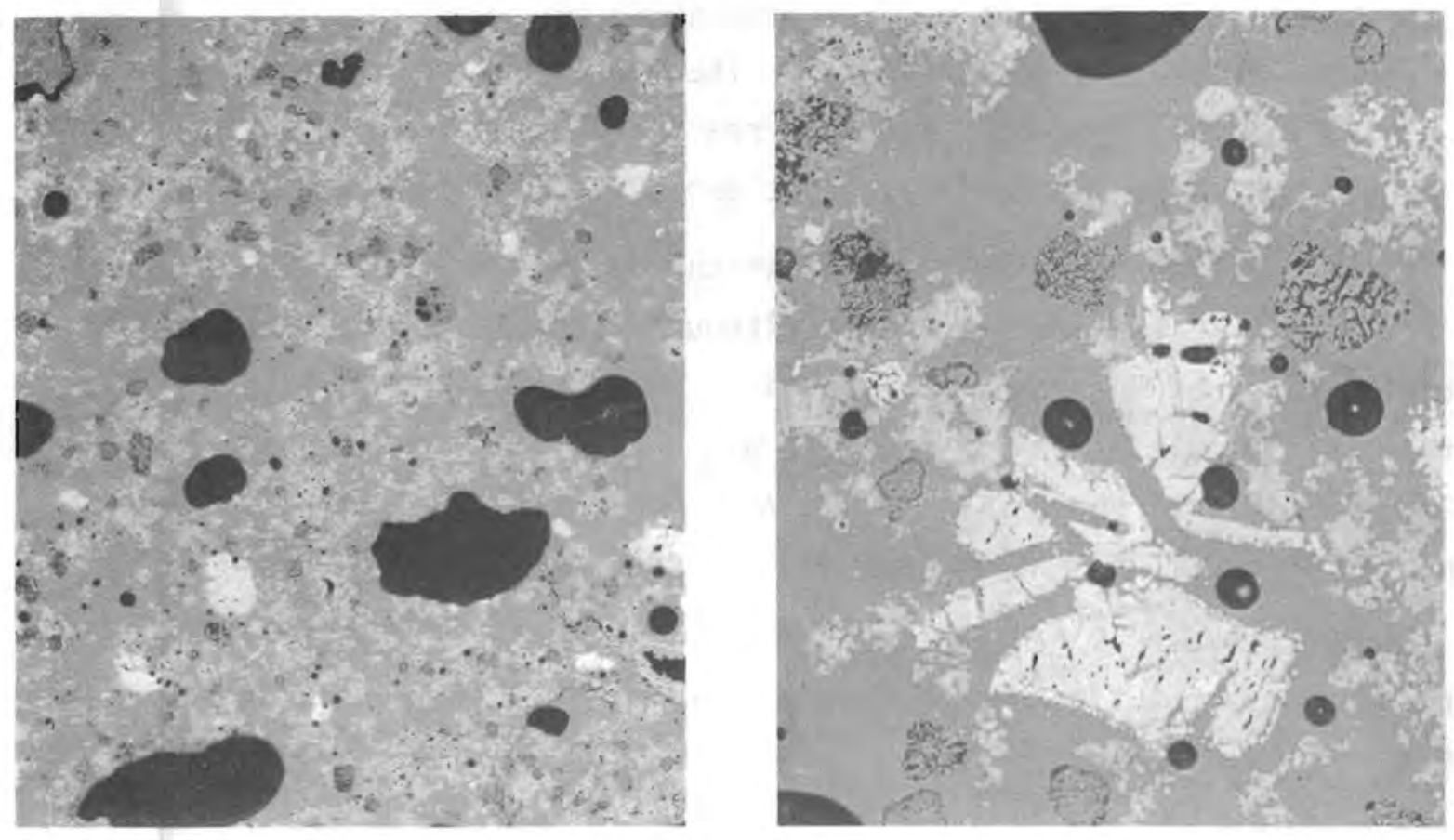

FIGURE 5. Photomicrographs of 28-wt\% Simulated TDS-2 Calcine/ $72-w t \%$ Frit Batch Heated to $750^{\circ} \mathrm{C}$ 


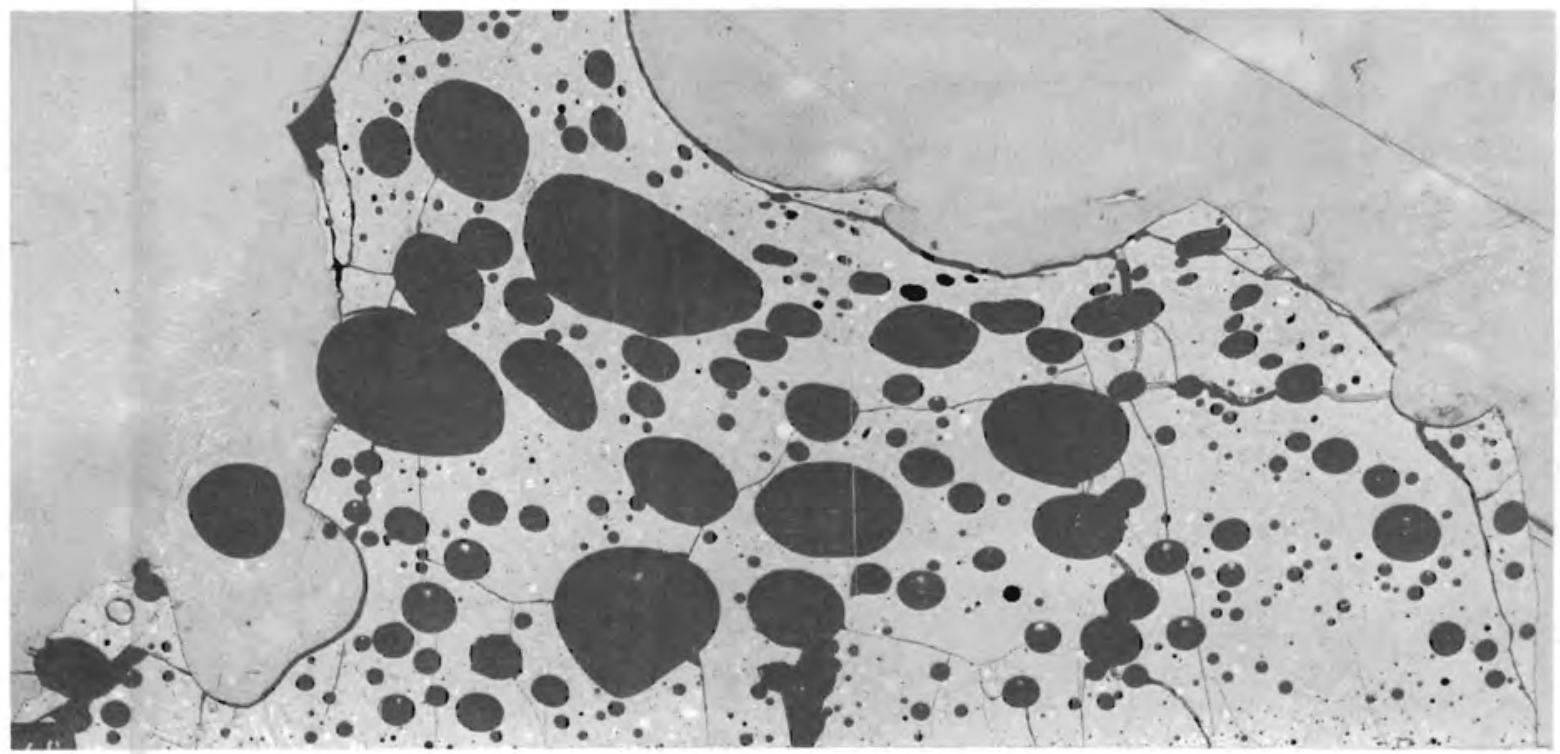

$8.9 x$
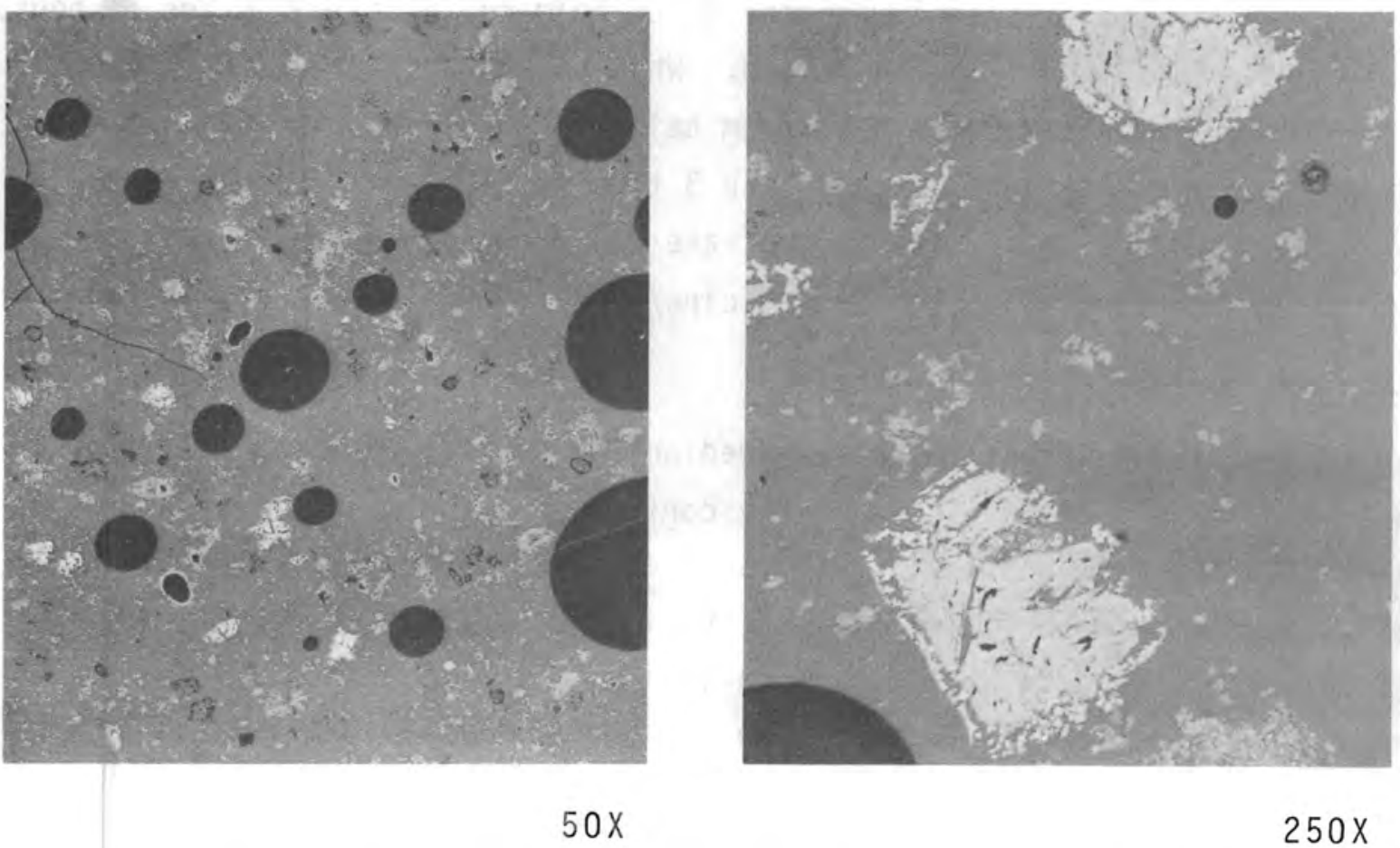

FIGURE 6. Photomicrographs of 28-wt\% Simulated TDS-2 Calcine/ $72-w t \%$ Frit Batch Heated to $800^{\circ} \mathrm{C}$ 


\section{THE WASTE}

Investigations of the simulated waste to find the source of the foamcausing gas were originally focused on the residual carbonates, hydroxides and nitrates remaining in the batch due to incomplete calcination. The carbonaceous materials and sodium sulfate in the waste were also given a lot of attention because our literature review strongly implicated these substances whenever glass melts foamed. However, by following the lead provided by Prof. L. D. Pye (Pye 1979), we were able to demonstrate that oxides of iron and manganese were the source of the gas.

\section{Incomplete Calcining}

When melted the calcine/frit batches lose 3 to $5 \mathrm{wt} \%$ due to the decomposition of carbonate, hydroxide and nitrate compounds in the waste that have survived the calcination process. The presence of a glass phase in the melt could trap these decomposition gases and cause foaming. To investigate this possibility, calcine was completely decomposed by holding it at $1000^{\circ} \mathrm{C}$ for 15 hours. It was then mixed with frit and melted. While there was virtually no weight loss during this melting test, the foam height was the same as it is with standard calcine/frit batches that lose 3 to $5 \mathrm{wt}$. Therefore, the decomposition of carbonate, hydroxide and nitrate compounds in the waste does not account for the foaming noted with calcine/frit batches.

\section{Carbon and Sodium Sulfate}

Because nearly every paper reviewed on the subject of glass melt foaming mentioned sodium sulfate as one of the contributing factors (Cable, Rasul and Savage 1968, Manring and Davis 1977, Scholes 1975, Conroy, Manring and Bauer 1966), tests were done to investigate the interactions of carbon and sodium sulf ate with respect to melt foam heights in the 28-wt\% TDS-2/72-wt\% frit batch composition. The levels of the carbon and the sodium sulfate evaluated and the resulting foam heights are presented in Table 6.

The carbon levels were adjusted by reducing the anthracite, cornstarch, and $\mathrm{Na}_{4}$ EDTA contents of the batch without altering the relative amounts of these three carbon-containing components, except in the batch containing 
TABLE 6. Carbon and Sodium Sulfate Concentrations Evaluated and the Resulting Foam Heights

\begin{tabular}{|c|c|c|c|c|}
\hline $\begin{array}{c}\text { Carbon Content, } \\
\text { wt\% }\end{array}$ & $\begin{array}{c}\mathrm{Na}_{2} \mathrm{SO}_{4} \\
\text { Wt\% } \\
\text { wtent, }\end{array}$ & $\begin{array}{l}\text { Number of } \\
\text { Melts Made }\end{array}$ & $\begin{array}{l}\text { Mean Foam } \\
\text { Height, } \mathrm{mm}\end{array}$ & $\begin{array}{c}\text { Standard } \\
\text { Deviation, } \mathrm{mm}\end{array}$ \\
\hline 0 & 0 & 4 & 36.1 & 1.8 \\
\hline 1.28 & 0 & 3 & 32.8 & 2.1 \\
\hline 2.50 & 0 & 1 & 36.1 & -- \\
\hline 5.00 & 0 & 1 & 44.7 & -- \\
\hline 0 & 0 & 1 & 39.4 & -- \\
\hline 1.28 & 0.25 & 1 & 32.5 & -- \\
\hline 2.50 & 0.25 & 1 & 42.4 & -- \\
\hline 5.00 & 0.25 & 1 & 38.9 & -- \\
\hline 0 & 0.4 & 3 & 32.2 & 3.1 \\
\hline 0.67 & 0.4 & 1 & 30.2 & -- \\
\hline 1.28 & 0.4 & 5 & 33.0 & 2.2 \\
\hline 0 & 0.5 & 1 & 38.6 & -- \\
\hline 2.50 & 0.5 & 1 & 35.3 & -- \\
\hline 5.00 & 0.5 & 1 & 35.0 & -- \\
\hline
\end{tabular}

0.67-wt\% carbon. This batch was prepared by leaving all the $\mathrm{Na}_{4}$ EDTA out and putting anthracite and cornstarch in at the usual concentrations for the standard TDS-2 composition. The standard composition with $\mathrm{Na}_{4}$ EDTA contains 1.28-wt\% carbon and 0.4-wt\% $\mathrm{Na}_{2} \mathrm{SO}_{4}$. Although many more melts should be run to develop statistically significant results, the 1 imited response surface presented in Figure 7 does show the sodium sulfate content of 0.4 wt\% is about correct for achieving the minimum foam height with this batch composition. However, the standard carbon content appears to be excessive. Reducing the carbon content one-half by eliminating the $\mathrm{Na}_{4}$ EDTA from the waste stream could produce the minimum foam level possible through optimizing the carbonsodium sulfate interaction. However, this minimum is only a $14 \%$ reduction in the foam height. Although these results show the carbon-sodium sulfate interaction is not the major cause of the foam, studies are recommended to investigate the interactions of carbon and of sodium sulfate with the oxides of the multivalent ions in the waste. 


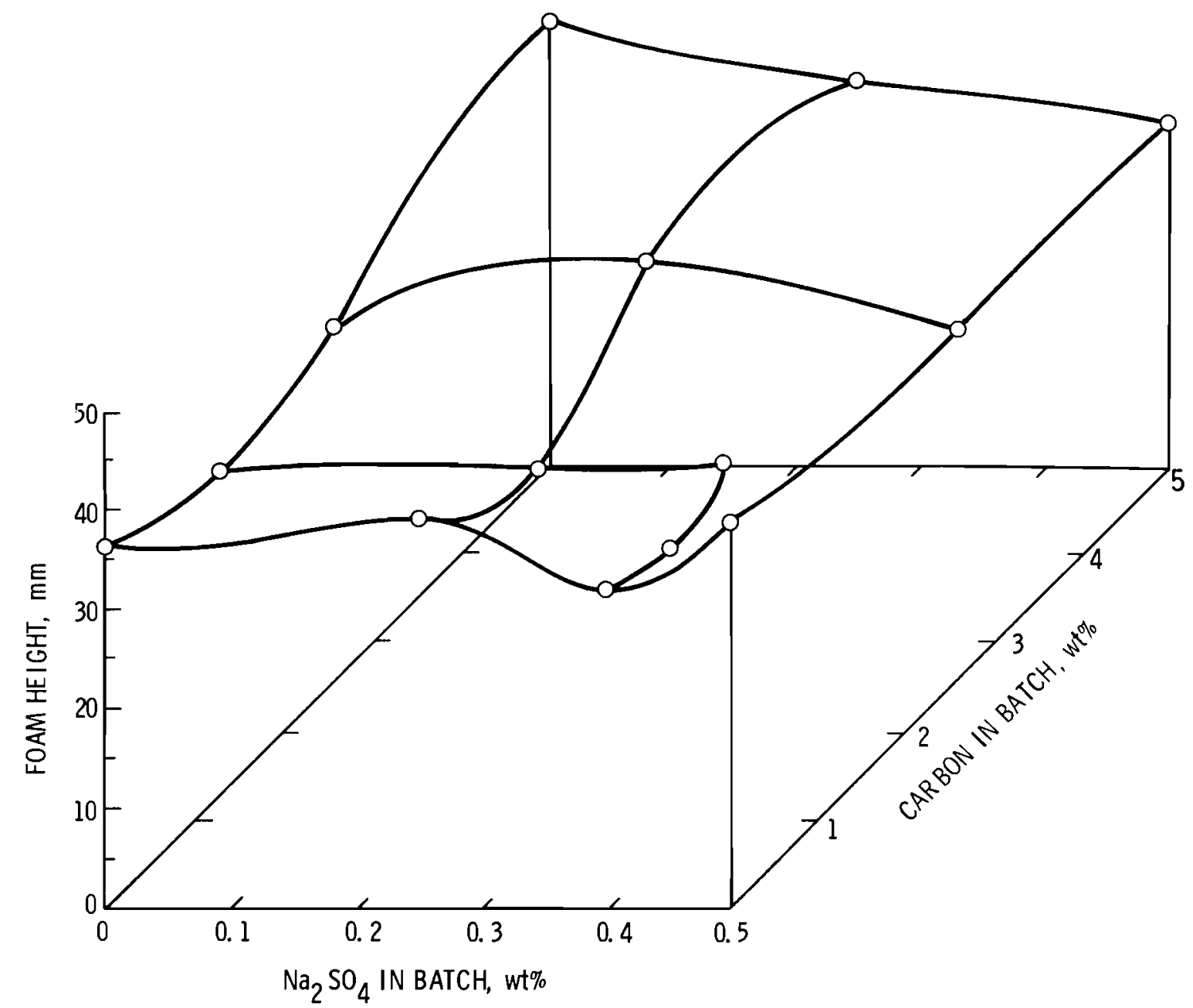

FIGURE 7. Foam Heights as a Function of Carbon and $\mathrm{Na}_{2} \mathrm{SO}_{4}$ Contents

\section{Oxidation States of Multivalent Ions}

During their work on the foaming of nuclear waste melts performed in 1979 for PNL, Prof. L. D. Pye and his associates at Alfred University found that the multivalent ions of manganese, iron and nickel are associated with the generation of oxygen bubbles in the melts (Pye 1979). Therefore, one of the first substitutions made when preparing simulated calcines was replacing the $\mathrm{MnO}_{2}$ and $\mathrm{Fe}_{2} \mathrm{O}_{3}$ with $\mathrm{MnO}$ and $\mathrm{FeO}$, respectively, on an equivalent-moles-of-metal basis. The initial tests were made with the TDS composition and used $16 \mathrm{~g}$ of batch in 
a crucible. The results are presented in Table 7 . These initial results showed that the oxidation states of iron and manganese significantly affected foaming.

Later tests were made using the TDS-2 composition and $25 \mathrm{-g}$ samples. The number of variables was increased to investigate the effects of various components in the waste on foaming behavior and to investigate the interaction of carbon and sodium sulfate with the oxides of the multivalent ions. The initial batches made with the simulated TDS-2 composition were divided and two melting runs were made. Then new batches were prepared and melted in a third, and in some instances a fourth, run. The results are presented in Table 8 . Although foam height varied considerably from run to run, the ranking within a run was consistent enough to draw several conclusions. The most interesting result was that the foam height was most significantly reduced by reducing the oxidation state of the manganese. To investigate this result further, the fourth series was run in which one sample contained no manganese at all. The results suggest that manganese oxides are the major cause of the initial foaming as the batch melts. However, because there is so much of it and because the melting temperatures are much higher than the $1050^{\circ} \mathrm{C}$ used for these tests, iron oxide is suspected to play a significant part in the foaming of the melt in a continuous melter operation.

This series of tests also showed that $\mathrm{Na}_{2} \mathrm{SO}_{4}$ in the batch improves the homogeneity of the melt and that carbon helps reduce foam height. However, the use of the monoxides of iron and manganese in the simulated calcine has the greatest effect on foam height reduction.

TABLE 7. The Effects of Substitutions Made in the Preparation of Simulated TDS Waste Calcine on Foam Height and Product Quality

\begin{tabular}{|c|c|c|c|}
\hline Substitution & $\begin{array}{c}\text { Foam Height, } \\
\mathrm{mm} \\
\end{array}$ & $\begin{array}{c}\text { Weight Percent } \\
\text { Lost }\end{array}$ & Product Quality \\
\hline None & 26.9 & 3.8 & homogeneous \\
\hline None & 24.6 & 4.8 & slag \\
\hline $\mathrm{FeO}$ and $\mathrm{MnO}$ & 29.0 & 3.4 & homogeneous \\
\hline $\mathrm{FeO}$ & 18.3 & -- & viscous melt \\
\hline MnO & 18.5 & 0.25 & heterogeneous \\
\hline
\end{tabular}


TABLE 8. Results of Investigation to Determine Effects of Various Components in TDS-2 Waste on Foam Height and Product Quality

\begin{tabular}{|c|c|c|c|c|c|c|}
\hline \multirow[b]{2}{*}{ Variables } & \multicolumn{4}{|c|}{ Foam Height, mm } & \multirow{2}{*}{$\begin{array}{l}\text { Weight Percent } \\
\text { Lost }\end{array}$} & \multirow{2}{*}{$\begin{array}{l}\text { Product } \\
\text { Quality }\end{array}$} \\
\hline & Run 1 & Run 2 & Run 3 & Run 4 & & \\
\hline None & 33.3 & spilled & 32.0 & 35.0 & $4.17,4.32$ & homogeneous \\
\hline $\mathrm{FeO}$ and $\mathrm{MnO}$ & 29.5 & 31.8 & 31.2 & -- & 2.40 & homogeneous \\
\hline $\mathrm{Fe} 0$ & 28.2 & 41.4 & 32.0 & -- & 4.30 & homogeneous \\
\hline $\mathrm{MnO}$ & 27.7 & 31.0 & 28.7 & 30.5 & $4.00,4.03$ & homogeneous \\
\hline No $\mathrm{Mn}$ & -- & -- & -- & 29.5 & 3.85 & homogeneous \\
\hline $\begin{array}{l}\mathrm{FeO}, \mathrm{MnO}, \text { and } \\
\text { no C or } \mathrm{SO}_{4}\end{array}$ & 31.2 & 37.6 & 35.3 & -- & 1.50 & homogeneous \\
\hline $\begin{array}{l}\mathrm{Fe} 0, \mathrm{MnO} \text { and } \\
\text { no } \mathrm{C}\end{array}$ & 37.3 & 32.5 & 32.5 & -- & 1.73 & homogeneous \\
\hline $\begin{array}{c}\mathrm{FeO}, \mathrm{MnO} \text { and } \\
\text { no. } \mathrm{SO}_{4}\end{array}$ & 34.5 & 38.1 & 36.8 & -- & 3.75 & thick scum \\
\hline No $\mathrm{C}$ or $\mathrm{SO}_{4}$ & 38.6 & 34.5 & 35.8 & -- & 2.58 & homogeneous \\
\hline No $\mathrm{C}$ & 34.5 & 38.1 & 32.0 & -- & 2.67 & homogeneous \\
\hline $\mathrm{No} \mathrm{SO}_{4}$ & 30.2 & 33.8 & 34.0 & -- & 4.56 & thick scum \\
\hline
\end{tabular}




\section{EVALUATION OF METHODS TO REDUCE FOAMING}

Even before the actual source of the foam-causing gas was known, we began testing methods reported to have reduced or controlled glass melt foaming. We concentrated on the chemistry of the batch rather than on the mechanical aspects and operation of the melters because the former was felt to be the way to prevent foaming rather than to just accommodate or control it when it appeared. However, we did investigate the effects of better batch mixing, waste loadings, and melter-tank configurations on foaming. After we understood the source of the gas, we focused on steps that would affect the oxidation state of the iron and manganese in the batch such as adding reducing agents, controlling the melter atmosphere, and processing the waste calcine prior to melting. A more detailed discussion of each method studied follows.

\section{$\underline{\text { BATCH MIXING }}$}

Melt tests were performed that compared the foaming of batches prepared by simply stirring a blend of calcined TDS waste and $-20 / 80$ mesh frit with those prepared by grinding the mixture with a pestle and mortar to -100 mesh. While the homogeneity of the product was much improved, the well mixed batch prepared by grinding foamed only a little less than did the stirred batch.

\section{WASTE LOADINGS}

A series of melt tests was done to investigate the effect of waste loading on foam height. The waste loadings investigated and the resulting foam heights and product quality are presented in Table 9. Batches loaded with 14-wt\% simulated waste or less did not foam as they melted and the glasses were homogeneous. However, batches containing $28-w t \%$ or more simulated waste foamed and produced glasses with a nonvitreous slag around the edges of the melt and/or a nonvitreous scum on the surface of the glass. Reducing the waste loading to 14 wt\% or less to control foam is not a satisfactory solution to improving the processing rate because it requires producing twice as much glass to vitrify the same amount of waste. 
TABLE 9. Effects of Simulated-Waste Loadings on Foam Heights and Product Quality

\begin{tabular}{|c|c|c|c|c|c|}
\hline Batch Composition & $\begin{array}{l}\text { Sample } \\
\text { Size, g }\end{array}$ & $\begin{array}{c}\text { Waste } \\
\text { Load, wt\% }\end{array}$ & $\begin{array}{c}\begin{array}{c}\text { Foam } \\
\text { Height, }\end{array} \\
\end{array}$ & $\begin{array}{l}\text { Weight } \\
\text { Lost, wt\% }\end{array}$ & $\begin{array}{l}\text { Product } \\
\text { Quality }\end{array}$ \\
\hline TDS + Frit & 16 & 7 & 13.5 & 3.72 & homogeneous \\
\hline TDS + Frit & 16 & 14 & 19.6 & 2.88 & homogeneous \\
\hline TDS + Frit & 16 & 28 & 19.6 & 3.69 & scum \\
\hline $\begin{array}{l}\text { TDS + Frit }+ \\
1 \% \text { cornstarch }\end{array}$ & 16.16 & 28 & 19.0 & 4.52 & slag and scum \\
\hline TDS + Frit & 16 & 35 & 19.0 & 3.94 & scum \\
\hline TDS + Frit & 16 & 42 & 20.6 & 4.17 & slag and scum \\
\hline TDS + Frit & 25 & 8 & 21.8 & 2.61 & homogeneous \\
\hline TDS + Frit & 25 & 10 & 20.8 & 2.46 & homogeneous \\
\hline TDS + Frit & 25 & 12 & 20.6 & 2.79 & trace slag \\
\hline TDS + Frit & 25 & 14 & 21.8 & 2.77 & slag \\
\hline TDS + Frit & 25 & 28 & 25.9 & 3.62 & scum and slag \\
\hline $\begin{array}{l}\text { TDS }+ \text { Frit }+ \\
1 \% \text { cornstarch }\end{array}$ & 25.25 & 28 & 26.2 & 5.16 & slag \\
\hline TDS-2 + Frit & 25 & 7 & 22.4 & 0.58 & -- \\
\hline TDS-2 + Frit & 25 & 14 & 19.8 & 2.04 & homogeneous \\
\hline TDS $-2+$ Frit & 25 & 28 & 24.9 & 3.19 & homogeneous \\
\hline
\end{tabular}

\section{ADDITIVES}

As previously noted, changes in the oxidation state of the glass can result in some dissolved gases coming out of solution, and enough bubbles in the molten glass would produce foam. A reducing agent lowers the oxygen content by readily reacting with available oxygen in the batch before melting begins. Small amounts of graphite and oil are routinely used to reduce some commercially produced glasses. High fission-product waste glasses have been reduced by the addition of silican metal (Ross 1978). Several melting trials were run to examine the impact of carbohydrate, carbon compound and metallic reducing agents on the foaming of SRP-13 batch. Each reducing agent was thoroughly mixed with the batch before melting at $1050^{\circ} \mathrm{C}$ for twenty minutes. Three concentration levels, 1,5 and $8 w t \%$, were initially tested. 
Table 10 lists the reducing agents that were tested and the resulting batch weight losses and foam heights. At the 1-wt\% level, all the agents reduced foam height by over $30 \%$. When added at $5 \mathrm{wt} \%$, the carbonaceous materials such as coal, charcoal and graphite usually produced a crystalline material on the melt surface. These additives reduced 1 - to $10-\mathrm{mm}$ metallic spheres from the melts when added at $8 \mathrm{wt} \%$. All metal-reducing agents when added at more than 5 wt\% produced a porous heterogeneous mass that contained little glass phase. The carbohydrate additives, sugar and cornstarch, did not alter glass properties up to the 8 -wt\% level. Foaming was reduced over $50 \%$ by 5 - to 8-wt\% additions of carbohydrates. However, this beneficial effect is eliminated if the batch and reducing agent are heated to $400^{\circ} \mathrm{C}$ before melting. The weight loss of sugar and cornstarch as a function of temperature, as shown in

TABLE 10. The Effects on Foam Height of Adding Reducing Agents to SRP-13 Batch

\begin{tabular}{|c|c|c|c|}
\hline$\frac{\text { Reducing Agent }}{\text { None }}$ & $\begin{array}{l}\begin{array}{c}\text { Amount Added, } \\
\text { wt\% }\end{array} \\
0\end{array}$ & $\begin{array}{c}\begin{array}{c}\text { Foam Height, } \\
\text { in. }\end{array} \\
34.3\end{array}$ & $\begin{array}{l}\text { We ight Loss, } \\
\text { wt\% } \\
6.6\end{array}$ \\
\hline Sugar & $\begin{array}{l}1 \\
5 \\
8\end{array}$ & $\begin{array}{l}25.9 \\
25.4 \\
25.4\end{array}$ & $\begin{array}{r}7.1 \\
12.6 \\
15.5\end{array}$ \\
\hline Cornstarch & $\begin{array}{l}1 \\
5 \\
8\end{array}$ & $\begin{array}{l}26.9 \\
20.6 \\
20.6\end{array}$ & $\begin{array}{r}7.3 \\
12.6 \\
15.6\end{array}$ \\
\hline 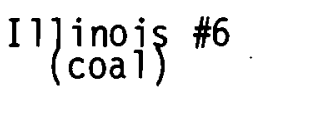 & $\begin{array}{l}1 \\
5 \\
8\end{array}$ & $\begin{array}{l}26.2 \\
22.4 \\
22.4\end{array}$ & $\begin{array}{r}7.4 \\
12.2 \\
14.3\end{array}$ \\
\hline Si (metal) & $\begin{array}{l}1 \\
5 \\
8\end{array}$ & $\begin{array}{l}24.6 \\
31.0 \\
32.0\end{array}$ & $\begin{array}{l}5.9 \\
5.5 \\
4.2\end{array}$ \\
\hline Al (metal) & $\begin{array}{l}1 \\
5 \\
8\end{array}$ & $\begin{array}{l}26.2 \\
26.9 \\
33.3\end{array}$ & $\begin{array}{l}5.9 \\
4.7 \\
4.3\end{array}$ \\
\hline $\mathrm{Fe}$ (metal) & $\begin{array}{l}1 \\
5 \\
8\end{array}$ & $\begin{array}{l}26.9 \\
24.1 \\
24.1\end{array}$ & $\begin{array}{l}6.0 \\
5.1 \\
4.7\end{array}$ \\
\hline Graphite & $\begin{array}{l}1 \\
5 \\
8\end{array}$ & $\begin{array}{l}26.2 \\
21.3 \\
21.1\end{array}$ & $\begin{array}{r}7.7 \\
12.1 \\
13.1\end{array}$ \\
\hline $\begin{array}{l}\text { Activated } \\
\text { charcoal }\end{array}$ & $\begin{array}{l}1 \\
5 \\
8\end{array}$ & $\begin{array}{l}25.4 \\
23.9 \\
22.6\end{array}$ & $\begin{array}{r}7.8 \\
6.5 \\
13.0\end{array}$ \\
\hline
\end{tabular}


Figure 8 , indicates that both materials are largely decomposed at $400^{\circ} \mathrm{C}$. It was difficult to reduce metals from the melt with carbohydrate agents. When more than 10-wt\% carbohydrates were added, they could be seen burning in the crucibles. It was necessary to add over $18-w t \%$ cornstarch to significantly alter melt properties. However, another interesting result of this series of melt tests presented in Table 9 was the fact that the addition of 1-wt\% cornstarch to the batches made with simulated TDS and TDS-2 calcines had no foamreducing affect as it had on the SRP-13 batch.

Because of the promising results achieved by adding cornstarch to the SRP-13 batch and because adding a small percentage of some agent to the batch along with the frit would be such an easy processing step to minimize the foam,

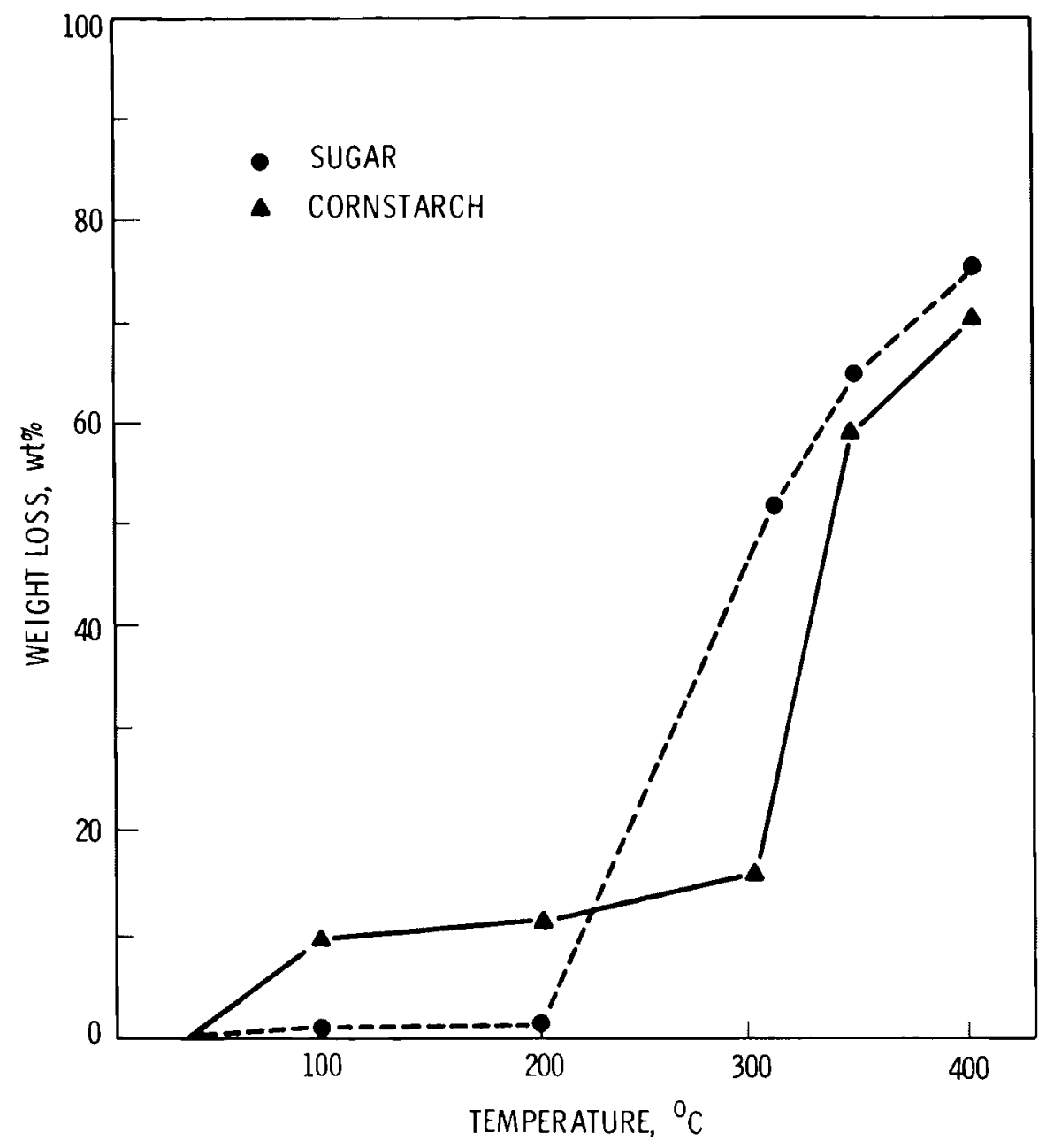

FIGURE 8. Carbohydrate Weight Loss Versus Temperature 
various other additives were tested. Reducing agents (usually a carbon compound) were found to be most effective with the TDS composition, while the oxidizing agents (such as $\mathrm{As}_{2} \mathrm{O}_{3}$ ) used by the glass industry for fining were most effective with the TDS-2 composition because of the carbonaceous materials already in it. The various additives tested and the resulting foam heights are reported in Table 11. The results are discussed briefly below.

The SiC was added as -200 mesh powder to the SRP-13 batch. The addition of the SiC at the levels tested resulted in more foam than the control melt and in an inferior product because more slag was produced. The urea was ground to

TABLE 11. The Effects of Additives on Foam Height and Product Quality

\begin{tabular}{|c|c|c|c|c|c|c|}
\hline Additives & Weight Percent & Batch Composition & $\begin{array}{l}\text { Sample } \\
\text { Size, g }\end{array}$ & $\begin{array}{c}\text { Foam } \\
\text { Height, mm }\end{array}$ & $\begin{array}{l}\text { Weight Percent } \\
\text { Lost }\end{array}$ & $\begin{array}{l}\text { Product } \\
\text { Quality }\end{array}$ \\
\hline None & & SRP-13 & 16 & 23.1 & 4.9 & slag \\
\hline Cornstarch & 1 & SRP -13 & 16 & 16.8 & 5.4 & scum \\
\hline $\mathrm{SiC}$ & 0.5 & $S R P-13$ & 16 & 26.9 & 5.1 & slag \\
\hline $\mathrm{SiC}$ & 1 & SRP-13 & 16 & 25.4 & 5.8 & slag and scum \\
\hline $\mathrm{SiC}$ & 1.5 & SRP -13 & 16 & 24.6 & 4.2 & slag and scum \\
\hline Urea & 0.5 & SRP-13 & 16 & 25.4 & 6.5 & slag \\
\hline Urea & 1 & SRP-13 & 16 & 25.4 & 12.1 & slag \\
\hline Urea & 1.5 & SRP -13 & 16 & 23.1 & 3.3 & slag \\
\hline Activated charcoal & 0.5 & SRP -13 & 16 & 22.4 & 6.8 & slag and scum \\
\hline Activated charcoal & 1 & SRP -13 & 16 & 20.6 & 7.1 & slag and scum \\
\hline Activated charcoal & 1.5 & SRP -13 & 16 & 20.6 & 9.3 & $\begin{array}{l}\text { trace slag } \\
\text { and scum }\end{array}$ \\
\hline $\mathrm{As}_{2} \mathrm{O}_{3}$ & 1 & SRP -13 & 16 & 27.4 & 5.5 & slag and scum \\
\hline None & & FSSC-37+frit & 25 & 23.4 & 7.71 & trace slag \\
\hline $\mathrm{As}_{2} \mathrm{O}_{3}$ & 1 & FSSC $-37+$ frit & 25 & 24.6 & 8.6 & trace scum \\
\hline $\mathrm{As}_{2} \mathrm{O}_{3}$ & 2 & FSSC-37+frit & 25 & 21.1 & 7.4 & trace scum \\
\hline $\mathrm{H}_{2} \mathrm{O}$ & .034 & FSSC $-37+$ frit & 25 & 24.6 & 7.5 & trace slag \\
\hline $\mathrm{H}_{2} \mathrm{O}$ & 0.76 & FSSC $-37+f r i t$ & 25 & 24.1 & 8.3 & trace slag \\
\hline $\mathrm{H}_{2} \mathrm{O}$ & 2.1 & FSSC-37+frit & 25 & 24.9 & 9.2 & trace slag \\
\hline $\mathrm{H}_{2} \mathrm{O}$ & 4 & FSSC $-37+$ frit & 25 & 24.6 & 11.2 & trace scum \\
\hline $\mathrm{H}_{2} \mathrm{O}$ & 8 & FSSC $-37+$ frit & 25 & 27.7 & 14.5 & trace scum \\
\hline None & & $\begin{array}{l}\text { Simulated TDS }-2+ \\
\text { frit }\end{array}$ & 25 & 35.0 & 4.5 & homogeneous \\
\hline $\mathrm{Ba}\left(\mathrm{PO}_{3}\right)_{2}$ & 1 & $\begin{array}{l}\text { Simulated TDS-2+ } \\
\text { frit }\end{array}$ & 25 & 29.7 & 4.2 & homogeneous \\
\hline $\mathrm{Ba}\left(\mathrm{PO}_{3}\right)_{2}$ & 2 & $\begin{array}{l}\text { Simulated TDS-2+ } \\
\text { frit }\end{array}$ & 25 & 28.7 & 4.2 & homogeneous \\
\hline $\mathrm{Ba}\left(\mathrm{PO}_{3}\right)_{2}$ & 4 & $\begin{array}{l}\text { Simulated TDS-2+ } \\
\text { frit }\end{array}$ & 25 & 30.5 & 4.2 & homogeneous \\
\hline $\mathrm{Ba}\left(\mathrm{PO}_{3}\right)_{2}$ & 8 & $\begin{array}{l}\text { Simulated TDS }-2+ \\
\text { frit }\end{array}$ & 25 & 31.2 & 4.1 & homogeneous \\
\hline
\end{tabular}


-100 mesh and was mixed with the SRP-13 batch. The foam levels were the same or higher than the control and the quality of the product was worse because of excessive slag.

Activated charcoal (Calgon $\mathrm{OL}^{\circledR} 20 \times 50$ ) was again evaluated in amounts ranging from 0.5 to $1.5 \mathrm{wt} \%$ because experience at SRL showed this material to be more effective than cornstarch for reducing foam in a small bench-scale electric melter. The results (Table 11) show that cornstarch is more effective than charcoal in preventing foam in crucible melts of SRP-13 batch.

The addition of $1-w t \% \mathrm{As}_{2} \mathrm{O}_{3}$ to SRP-13 increased the foam height, while adding 2-wt\% $\mathrm{As}_{2} \mathrm{O}_{3}$ to a batch made with FSSC-37 calcine and frit slightly reduced the foam height. These results make sense because $\mathrm{As}_{2} \mathrm{O}_{3}$ is an oxidizing agent and the SRP-13 calcine makes an oxidizing melt, while FSSC-37 calcine, which was the TDS-2 composition, contains considerable reducing agent.

Water is commonly added to glass batch in the glass industry to control dusting and to prevent the batch components from separating after they are mixed. Such batch wetting is believed to also affect the redox balance in the melter (Manring and Davis 1977). Therefore, up to 8-wt\% water was added to batch made with FSSC-37 calcine and frit to evaluate the effects on foam height. However, the water additions did not significantly affect the foam height.

Barium metaphosphate, which has a low melting point $\left(850^{\circ} \mathrm{C}\right)$ and a high solubility for iron oxide, is used to control boiling during firing of ceramic coatings on steel (Raw Materials Handbook, January 1980). Because iron oxide was one of the prime suspects in the foaming phenomenon, batches of simulated TDS-2 and frit were made with additions ranging from 1- to 8-wt\% vitrified $\mathrm{Ba}\left(\mathrm{PO}_{3}\right)_{2}$. All the batches containing barium metaphosphate foamed less than the control batch. Those containing 1 and 2 wt\% had the lowest foam heights, $26 \%$ lower than the control.

(8ctivated Carbon Div., Calgon Corp. 


\section{TESTS IN THE EXPERIMENTAL CERAMIC MELTER}

Because the results with cornstarch in the preliminary laboratory studies were good, a number of tests using it in SRP-13 batch were conducted in the melters at PNL. A test in a LFCM showed that foaming was not reduced when 0.5 -wt\% cornstarch was added to SRP-13 batch. In addition, when 5-wt\% cornstarch was added to the SRP-13 batch and tested in the ECM, so much iron and nickel alloy was deposited that the electric current flow short-circuited through the metal rather than through the melt. Therefore, tests were conducted in the ECM to determine the minimum amount of cornstarch that could be added and still reduce foam and the maximum amount that could be added before metals precipitated on the floor of the melter. Three batches of SRP-13 were prepared with $0.75-, 1.0-$ and 2.0-wt\% cornstarch. Fifty to $60 \mathrm{~kg}$ of each batch were melted at a $9-\mathrm{kg} / \mathrm{h}$ rate. Temperatures in the melter during the tests ranged from $480^{\circ} \mathrm{C}$ in the cold cap to $1260^{\circ} \mathrm{C}$ in the center of the melt (see Figure 1). After each batch was processed, the floor of the melter was probed to see if metal had been deposited.

No foaming occurred during the melting of any of the three batches and no metal was found on the floor of the melter. Current and voltage measurements throughout the melting tests indicated that no low-conductivity foam and no high-conductivity metals accumulated in the melter. Furthermore, analyses of batch and glass samples taken during the tests showed that no significant change in the metals' contents occurred during the melting process.

The fact that none of the test batches foamed in the ECM while similar batches had foamed in the full-scale melters lead to the consideration of factors other than batch composition that could be affecting foaming. For example, the cornstarch was more uniformly mixed with the batches melted in the ECM than it was with those used in the full-scale melters. In addition, a complete and uniformly thick cold cap is quickly established and easily maintained in the ECM. Therefore, the upper regions of the ECM are cool and the cornstarch is not instantly ignited as the batch enters the ECM like it is in the larger melters. Plenum temperatures in the ECM range from $118^{\circ} \mathrm{C}$ to $415^{\circ} \mathrm{C}$ during batch-charging onto an established cold cap. 
Both the size and relative proportions of the ECM are different from those of the larger melters. Davis, Bauer and Manring (1975) state that one requirement for maximum melting economy (minimized foam and melt segregation) is a deep glass bath. The dimensions of the five joule-heated melters (the benchscale ceramic melter--BSCM; the remote ceramic melter--RCM; the calcine-fed ceramic melter--CFCM; the ECM; and the LFCM) that are being operated at PNL (Buelt et al. 1979) are listed in Table 12 along with the surface-area-to-depth ratio for each tank and the maximum melting rates that have been sustained in each melter. According to Davis's criterion the ECM should provide the best melting results while the CFCM should have the most difficulties, but this hypothes is cannot be confirmed because of the many other variables involved when each melting rate was determined. However, when the melters' capacities are expressed as they are in the glass industry, i.e., area of the melter in $\mathrm{ft}^{2}$ per ton of glass produced per day, (as done in the final column of Table 12), it does look like greater melting efficiency is obtained in the PNL melters that are deeper relative to the tank surface area. The glass industry is able to achieve capacities approaching $2 \mathrm{ft}^{2} /$ ton $/ \mathrm{d}$ in modern glass melting tanks, and the capacity of the ECM, in which foaming did not occur, is about as good. The differences in the design and operation of the ECM and the fullscale demonstration melters operated at PNL may help explain why the results

TABLE 12. Melter Tank Dimensions and Melting Rates

\begin{tabular}{|c|c|c|c|c|c|}
\hline Melter $(a)$ & $\begin{array}{l}\text { Surface } \\
\text { Area, } \mathrm{m}^{2}\end{array}$ & $\begin{array}{c}\text { Melt Depth, } \\
\mathrm{m} \\
\end{array}$ & $\begin{array}{c}\text { Surface-Area } \\
\text { to-Depth Ratio }\end{array}$ & $\begin{array}{c}\text { Melting Rate, } \\
\mathrm{kg} / \mathrm{h}\end{array}$ & $\begin{array}{r}\text { Melting } \\
\text { Capacity, } \\
\mathrm{ft}^{2} / \text { ton/d } \\
\end{array}$ \\
\hline ECM & 0.054 & 0.15 & 0.36 & 9 & 2.45 \\
\hline BSCM & 0.124 & 0.22 & 0.56 & ${ }_{18}^{(b, c)}$ & $2.8^{(c)}$ \\
\hline RCM & 0.243 & 0.20 & 1.21 & 30 & 3.3 \\
\hline LFCM & 1.053 & 0.48 & 2.19 & $51^{(d)}$ & 8.4 \\
\hline CFCM & 0.757 & 0.32 & 2.36 & $64^{(d)}$ & 4.8 \\
\hline
\end{tabular}

(a) Buelt 1979

(b) Barnes 1980

(c) This rate was demonstrated using a batch composition that does not foam.

(d) McE lroy 1979 
obtained in the ECM with cornstarch additions were not reproducible in the larger melters. They may also indicate that changes are needed in the design and operation of the larger melters to reduce foaming and improve the processing rates and control.

ATMOSPHERE CONTROL

The atmosphere in a glass melter has long been recognized as a significant parameter in the foaming of the melting batch (Cable, Rasul and Savage 1968). Therefore, various tests were performed in the laboratory to determine how changes in the atmosphere above the SRL composition melts would affect foaming. In the first test a cover was simply placed on crucibles containing various batches to see if those batches that contained cornstarch foamed less when the oxygen supply was limited. This mechanism has been suggested to explain the reduction of foaming by charcoal additives in the laboratory melter at SRL. The results are presented in Table 13. There were no noticeable differences in the foam heights between the covered and uncovered crucibles.

The effects of the atmosphere were further studied by conducting crucible melt tests in an Inconel retort placed inside the laboratory furnace. Six

TABLE 13. Results of Contained Atmosphere Tests

\begin{tabular}{|c|c|c|c|c|c|}
\hline Variable & $\begin{array}{c}\text { Batch } \\
\text { Composition } \\
\end{array}$ & $\begin{array}{l}\text { Sample } \\
\text { Size, g }\end{array}$ & $\begin{array}{c}\text { Foam } \\
\text { Height, mm }\end{array}$ & $\begin{array}{l}\text { Weight } \\
\text { Percent } \\
\text { Lost } \\
\end{array}$ & $\begin{array}{l}\text { Product } \\
\text { Quality }\end{array}$ \\
\hline None & $S R P-13$ & 16 & 25.4 & 6.3 & slag and scum \\
\hline 1-wt\% cornstarch & SRP -13 & 16 & 16.8 & 7.2 & slag and scum \\
\hline $\begin{array}{l}\text { 1-wt\% cornstarch } \\
\text { covered }\end{array}$ & SRP -13 & 16 & 18.3 & 7.5 & slag and scum \\
\hline None & $\begin{array}{l}\text { Simulated TDS + } \\
\text { frit }\end{array}$ & 16 & 21.3 & 4.4 & trace scum \\
\hline 1-wt\% cornstarch & $\begin{array}{l}\text { Simulated TDS }+ \\
\text { frit }\end{array}$ & 16 & 18.3 & 5.2 & trace scum \\
\hline $\begin{array}{l}\text { 1-wt\% cornstarch } \\
\text { covered }\end{array}$ & $\begin{array}{l}\text { Simulated TDS + } \\
\text { frit }\end{array}$ & 16 & 17.5 & 8.2 & slag \\
\hline
\end{tabular}


different batches were meited at $1050^{\circ} \mathrm{C}$ in four different gases (air, argon, nitrogen, carbon monoxide) to determine the effects of inert and reducing atmospheres on foam height. The resuits of these tests are presented in Table 14. Figure 9 illustrates some of the effects on product quality that the different atmospheres caused. The results are discussed briefly below.

The glasses formed by heating the batches in air were amber, while those heated in the other three gases were green-gray. The foam heights of those melted in air were generally higher than those melted in the inert or reducing gases. The glasses produced in air were homogeneous, but there was a metallic scum on the surfaces of the first two listed in the table. A small solidified pool of $\mathrm{Na}_{2} \mathrm{SO}_{4}$ was present on the surface of the melt made from simulated TDS calcine.

Melting in argon produced homogeneous glasses with mirror-like metallic scums on the surface. There were metal nuggets in the glasses made from SRP-13 with cornstarch added and from the simulated TDS-2 calcine.

The batches melted in nitrogen produced vitreous products, but metallic scums were present on some melt surfaces and a metal nugget was found in the glass made with the simulated TDS-2.

Heating in carbon monoxide significantly reduced the foam levels, but none of the six batches produced a homogeneous glass. The products were a combination of vitrified material, slag and metal nuggets or metallic scums on the melt surfaces.

These results suggest the possibility of reducing foaming by controlling the atmosphere in the melter. They also show that the effectiveness of the various gases tested is related to the waste composition, i.e., nitrogen is most effective with SRP-13 and argon is most effective with simulated TDS calcine containing cornstarch. When using an inert gas there is the possibility of metals precipitating from the melt, and the reducing gas, $100 \% \mathrm{CO}$, does cause metal to separate from the melts.

Attempts were made to confirm the laboratory results in the electric melters at PNL by purging with either nitrogen or argon. However, the melters are not sealed as a retort is and are operated with a negative internal 
TABLE 14. Foam Heights of Selected SRP Batches Melted in Various Atmospheres

\begin{tabular}{|c|c|c|c|c|c|c|c|c|c|}
\hline \multirow{2}{*}{\multicolumn{2}{|c|}{$\begin{array}{c}\text { Batch } \\
\text { Composition } \\
\end{array}$}} & \multicolumn{2}{|c|}{ Air } & \multicolumn{2}{|c|}{ Argon } & \multicolumn{2}{|c|}{ Nitrogen } & Carbon & \multirow{2}{*}{$\frac{\text { Monoxide }}{\text { Product }}$} \\
\hline & & $\begin{array}{c}\text { Foam } \\
\text { Height, } \mathrm{mm}\end{array}$ & $\begin{array}{r}\text { Product } \\
\text { Quality } \\
\end{array}$ & $\begin{array}{l}\text { Foam } \\
\text { Height, mm }\end{array}$ & $\begin{array}{l}\text { Product } \\
\text { Quality }\end{array}$ & $\begin{array}{l}\text { Foam } \\
\text { Height, mm }\end{array}$ & $\begin{array}{l}\text { Product } \\
\text { Quality } \\
\end{array}$ & $\begin{array}{c}\text { Foam } \\
\text { Height, } \mathrm{mm}\end{array}$ & \\
\hline & SRP -13 & 31.0 & metallic scum & 31.7 & $\begin{array}{l}\text { homogeneous } \\
\text { glass }\end{array}$ & 26.7 & $\begin{array}{l}\text { heterogeneous } \\
\text { glass }\end{array}$ & 23.4 & $\begin{array}{l}\text { metallic slag } \\
\text { on glass }\end{array}$ \\
\hline & $\begin{array}{l}\text { Simulated TDS + } \\
\text { frit }\end{array}$ & 33.8 & homogeneous & 34.5 & $\begin{array}{l}\text { homogeneous } \\
\text { glass }\end{array}$ & 35.8 & $\begin{array}{l}\text { homogeneous } \\
\text { glass }\end{array}$ & 24.6 & $\begin{array}{l}\text { metal and slag } \\
\text { on glass }\end{array}$ \\
\hline & $\begin{array}{l}\text { Simulated TDS-2+ } \\
\text { frit }\end{array}$ & 32.2 & trace of scum & 32.2 & $\begin{array}{l}\text { metal nuggets } \\
\text { on glass }\end{array}$ & 28.9 & $\begin{array}{l}\text { homogeneous } \\
\text { glass and } \\
\text { metal nugget }\end{array}$ & 18.3 & $\begin{array}{l}\text { friable slag } \\
\text { no glass }\end{array}$ \\
\hline & $\begin{array}{l}\text { DSS - } 80-4+ \\
\text { frit }\end{array}$ & 27.7 & trace of scum & 26.7 & $\begin{array}{l}\text { metallic scum } \\
\text { on glass }\end{array}$ & 47.7 & $\begin{array}{l}\text { metallic scum } \\
\text { homogeneous } \\
\text { glass }\end{array}$ & 19.0 & $\begin{array}{l}\text { foam slag on } \\
\text { glass }\end{array}$ \\
\hline
\end{tabular}




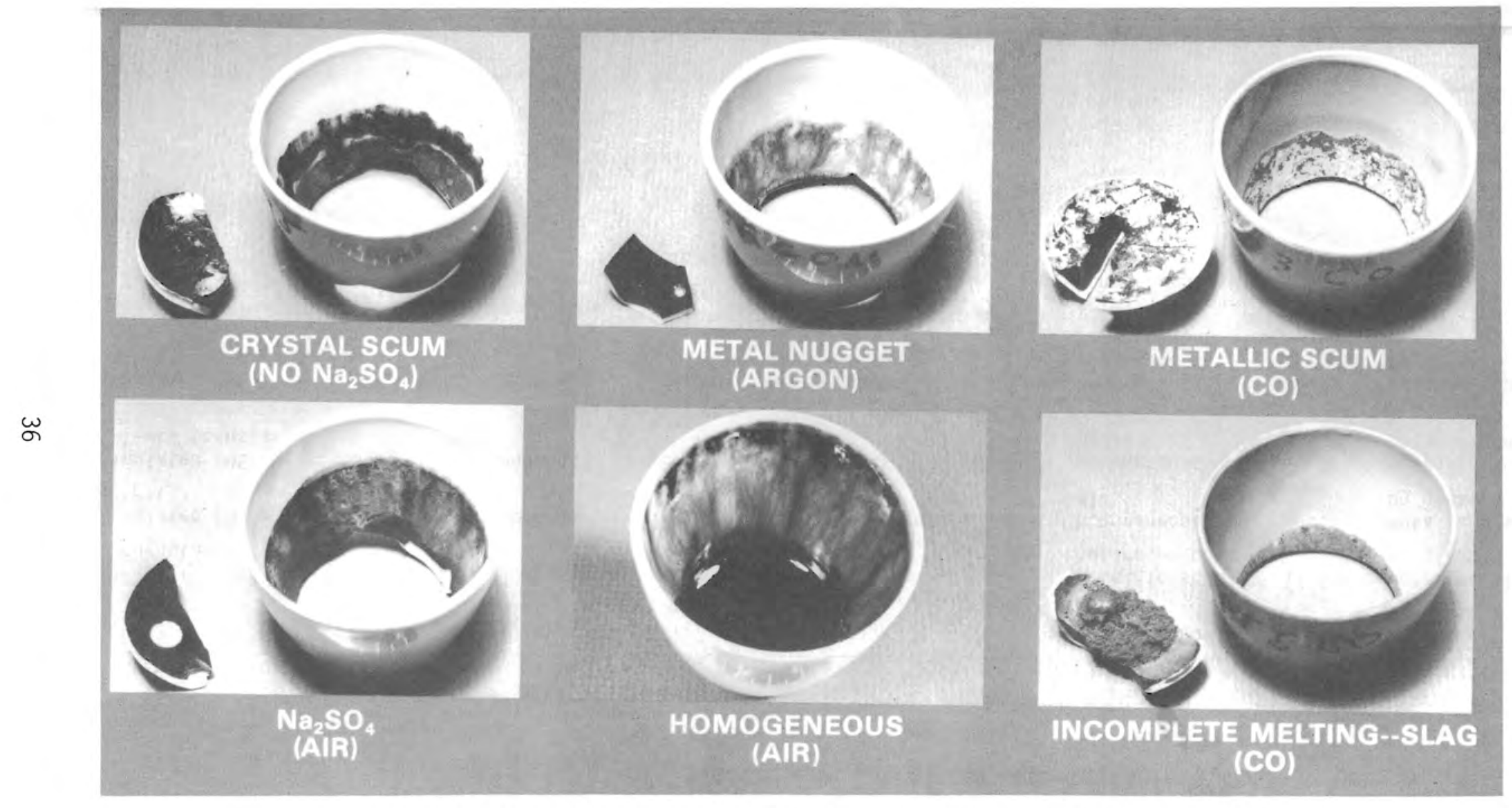

FIGURE 9. Effects of Different Atmospheres on Product Quality 
pressure for off-gas collection. Therefore, inleakage results in an air atmosphere over the melt even when the plenum is purged with some other gas. Controlling the atmosphere to reduce foaming will require redesigning of the melter containment to minimize air inleakage.

During the melting tests in the retort, the exhaust gases were vented through a water trap to prevent back migration of air. A yellow-green condensate was collected in the trap during each test. Analyses showed significant quantities of chlorine in this condensate. The chlorine in the effluents from melters processing SRP wastes requires special considerations when designing the effluent-treatment equipment.

\section{LIQUID WASTE TREATMENT}

Because changing the oxidation states of the multivalent ions by adding reducing agents and/or changing the atmosphere did not significantly reduce foaming, ways of treating the liquid waste to reduce the oxidation states of the manganese, iron and nickel oxides in the calcine were investigated. In the ir work on cermet waste forms at Oak Ridge National Laboratory, Aarons and Quinby (1979) suggested that oxidation states in the calcine might be reduced in a heated-wall spray calciner by adding sufficient quantities of urea to the liquid waste and then spraying it into the calciner with an inert atomizing gas. Series of laboratory and pilot-scale spray calciner tests were run at PNL to see what effects on foaming such liquid-feed processing would have. Simulated TDS-2 liquid waste was prepared according to the formula presented in Table 2. The slurries were diluted to a concentration of $60 \mathrm{~g}$ of oxides $/ \mathrm{L}$ and urea was added to some of the slurries at a concentration of $50 \mathrm{~g} / \mathrm{L}$. In the laboratory, the slurries were boiled dry in sealed flasks under a purge of air or nitrogen and were then mixed with 72-wt\% frit and melted in crucibles in an air atmosphere. Calcine was also prepared by processing the slurries in the pilot-scale spray calciner at PNL using nitrogen as the atomizing gas. These calcines were also blended with frit and melted to evaluate foam heights. The results did not show any significant decrease in foam heights as a result of these process changes. However, when the $\mathrm{MnO}_{2}$ content of the simulated 
waste fed to the calciner was reduced to less than 4 wt\% by settling in the solution make-up tank, the resulting calcines did not foam when melted with frit.

To determine the impact of calcination conditions on the manganese oxidation state, $\mathrm{MnO}_{2}$ samples were held for one hour at $400^{\circ} \mathrm{C}$ and $600^{\circ} \mathrm{C}$ in both air and $\mathrm{N}_{2}$ atmospheres. Upon cooling the samples were examined by $x$-ray diffraction to determine semiquantitatively how much of the tetragonal $\mathrm{MnO}_{2}$ was converted to cubic $\mathrm{Mn}_{2} \mathrm{O}_{3}$. The results presented in Table 15 show that the $\mathrm{MnO}_{2}$ must reach temperatures in excess of $400^{\circ} \mathrm{C}$ to be reduced to $\mathrm{Mn}_{2} \mathrm{O}_{3}\left(\mathrm{Mn}^{3+}\right)$. A nonoxidizing atmosphere such as $\mathrm{N}_{2}$ only slightly increases the conversion to $\mathrm{Mn}_{2} \mathrm{O}_{3}$. Under normal calciner operating conditions, the reduction of $\mathrm{MnO}_{2}$ to $\mathrm{MnO}$ is not anticipated even with a $\mathrm{N}_{2}$ atomizing gas. Some conversion of $\mathrm{MnO}_{2}$ to $\mathrm{Mn}_{2} \mathrm{O}_{3}$ is possible. Batches prepared using $\mathrm{Mn}_{2} \mathrm{O}_{3}$ as the manganese source did not reduce foaming as had been noted when MnO was used.

There are numerous processing steps that can be applied to treating the liquid waste and to operating of the calciner that could yet produce calcine containing the multivalent ions in the desired oxidation state. At this point it is important to determine the oxidation states of the actual waste constituents. This will help determine to what extent the foaming encountered using simulated wastes is a function of the simulation procedure or is representative of actual wastes.

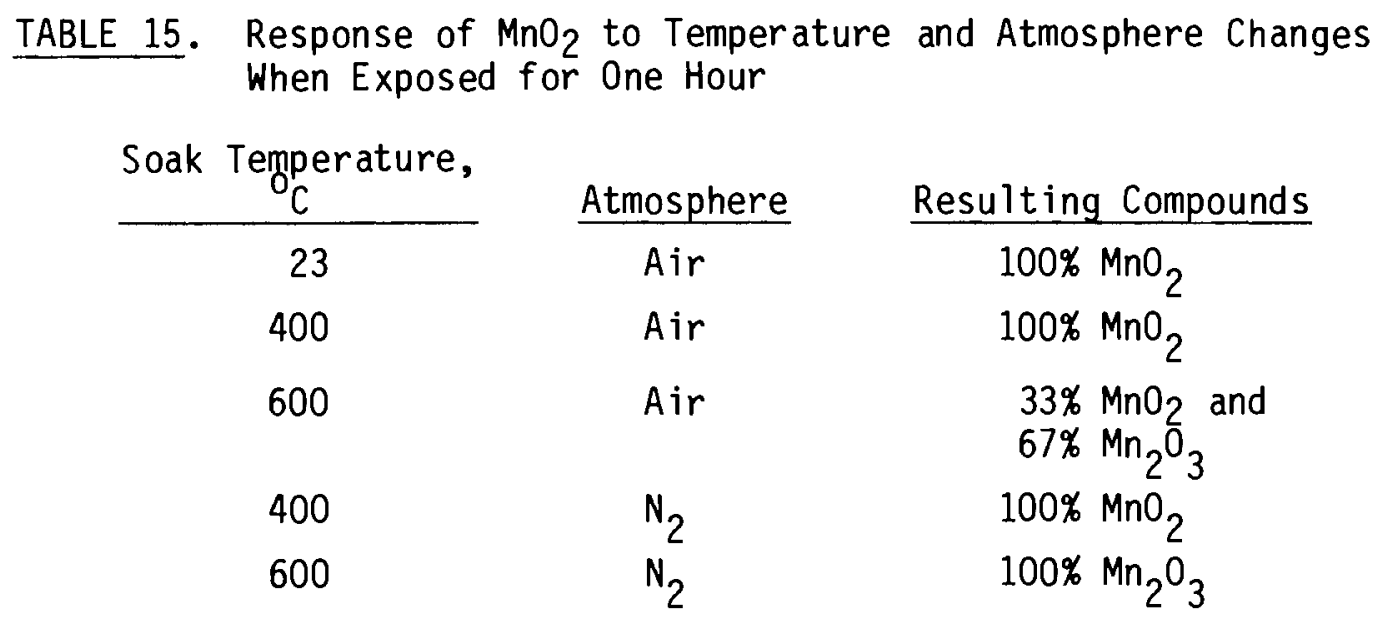




\section{CONCLUSIONS}

Crucible melts made in a laboratory furnace and even melting tests performed in the small ECM do not accurately represent the conditions or produce the same results that may be experienced in full-scale melters. However, much was learned about the melting process and those factors affecting foaming from such studies. The tests and results presented in this report showed the oxides of the multivalent elements in the waste are the source of the gas causing the foam, and reduction of these oxides to the lowest oxidation state was demonstrated in the laboratory to significantly reduce the foaming. The more specific conclusions about foaming of the SRP defense-waste simulations and frit studied are discussed below.

Replacing the frit with various glass-forming compounds does not have a significant effect on the foaming of the melting batch. Whether the glassforming compounds are oxides, carbonates, hydroxides or nitrates makes little difference in the foaming of the melting batch. Therefore, the frit is not the source of the gases causing foam in the defense-waste batches studied, but it is the first material in the batch to melt and impede the escape of these gases.

Calcining the TDS waste at temperatures high enough to convert all hydroxides, carbonates, and nitrates to oxides does not significantly affect the foam height.

The sodium sulfate content of the batch is important to the homogeneity of the product, but it is not a significant contributor to the foaming in the temperature range studied when the content does not exceed $0.4 \mathrm{wt} \%$. The optimum carbon and sodium sulfate contents for foam reduction in the 28-wt\% TOS-2/72 wt\% frit batch are $0.65-$ wt\% carbon and $0.4-$ wt\% sodium sulfate.

Changing the oxidation states of the multivalent ions of manganese and iron in the simulated waste had the most significant effect on foam height. Substituting $\mathrm{MnO}$ and $\mathrm{FeO}$ for $\mathrm{MnO}_{2}$ and $\mathrm{Fe}_{2} \mathrm{O}_{3}$, respectively, in simulated TDS-2 calcine reduced the foam height by $24 \%$, but substituting $\mathrm{Mn}_{2} \mathrm{O}_{3}$ for $\mathrm{MnO}_{2}$ did not reduce the foam. The nickel was assumed to always be in the lowest oxidation state and was not included as a variable in the study. 
Therefore, foaming of the SRP batch compositions studied is a function of the oxidation states of the multivalent elements, manganese and iron, in the waste. The manganese oxide is the cause of foaming in the initial stages of batch melting.

Adding various reducing agents, particularly carbon compounds, to the batch reduces the foam in some batch formulations. The addition of cornstarch is particularly effective in the SRP-13 composition, but has little effect in batches made with the TDS-2 composition. Use of carbonaceous additives in excess of 5 wt\% or use of strong reducing metal additives or strong reducing atmospheres in the retort results in separation of a metallic phase from the melt. Efforts to reduce foaming in the melter by adding reducing agents to the batch and/or controlling the atmosphere over the melt were not successful.

Adding 1- to 2 -wt\% barium metaphosphate to the batch causes a $26 \%$ reduction of the foam height in laboratory tests.

Initial attempts to produce the desired oxidation states in the calcined waste by using nitrogen as the atomizing gas and urea as a reducing additive in the liquid waste when processing in the heated-wall spray calciner were unsuccessful.

Reducing the waste loading in the batch to $14 \mathrm{wt} \%$ or less reduced the foam height by $38 \%$; however, such a reduction doubles the amount of vitrified product that must be processed by the melter.

The depth of the melter tank relative to the surface area of the melt and the distribution of the unmelted batch on the melt surface also appear to be critical factors in the control of the foaming behavior of the batch compositions studied. The ratio of surface area to depth that appears to provide the best results is less than 1 when the dimensions are expressed in meters.

The anticipated capacities of the electric melters have not yet been achieved when processing defense wastes, but we now know what the source of the foam-causing gas is and have demonstrated in the laboratory ways of reducing the foam. This understanding and demonstrated foam reduction provides assurance that the foam can be controlled and the desired melting rates will be realized in production-scale melters. 


\section{REFERENCES}

Aaron, W. S., T. C. Quinby, E. H. Kobisk, D. K. Thomas. 1979. "Study of Ceramic and Cermet Waste Forms," High-Level Waste Program Progress Report for April 1, 1979 Through June 30, 1979. ORNL/TM-7013, Oak Ridge Nationa 1 Laboratory, Oak Ridge, Tennessee.

Barnes, S. M. 1980. High-Temperature Vitrification of Hanford Residua 1Liquid Waste in a Continuous Melter, PNL-3343, Pacific Northwest Laboratory, Richland, Washington.

Bea 11, Geroge H. and Hermann L. Rittler. 1976. "Basalt Glass Ceramics," Ceramic Bulletin, 55 (6):579-582.

Buelt, J. L., et al. April 1979. A Review of Continuous Ceramic-Lined Melters and Associated Experience at PNL, PNL-SA-7590, Pacific Northwest Laboratory, Richland, Washington.

Cable, M., C. G. R. Rasul, and J. Savage. 1968. "Laboratory Investigation of Foaming and Reboil in Soda-Lime-Silica Melts," Glass Technology, $\underline{9}$ (2): $: 25-31$.

Chapman, C. C. et al. 1979. Vitrification of Hanford Wastes in a Joule-Heated Ceramic Melter and Evaluation of Resultant Canisterized Product, PNL-2904, Pac if ic Northwest Laboratory, Richland, washington.

Conroy, A. R., W. H. Manring, and W. C. Bauer. 1966. "The Role of Sulfate in the Melting and Fining of Glass Batch," The Glass Industry, Feb/Mar, Magazines for Industry, New York, New York.

Davis, R. E., W. C. Bauer, and W. H. Manring. 1975. Influence of Batch Charging on Furnace Operations and Fuel Economy, Paper presented at the 36 th Annual Conference on Glass Problems, University of 111 ino is, Urbana-Champaign, I11inois.

Manring, W. H. and R. E. Davis. 1977. The Role of the Raw Material Supplier in Energy Conservation for the Glass Industry, Paper presented at the 38th Annual Conference on Glass Problems, University of Illino is, Urbana-Champaign, Illino is.

Pye, L. D. 1979. Investigation of Controlling Mechanisms in Simulated Nuclear Waste Glass Melting and Gas Generation, New York State College of Ceramics, Alfred University, Alfred, New York.

McElroy, J. L. et al. 1979. Quarterly Progress Report--Research and Development Activities--High-Level Waste Immobilization Program: April through June 1979, PNL-3050-2, Pacific Northwest Laboratory, Richland, Washington. 
Miche11, R. and M. Brungs. 1976. "Controlled Glass Color Changes in Tank Furnaces," The Glass Industry, August, pp. 23-25, Magazines for Industry, New York New York.

Raw Materials Handbook. 1980. Ceramic Industry, 114(1):57. Cahners Publishing Co., Chicago, Illinois.

Ross, W. A. 1978. Development of Glass Formulations Containing High-Leve Nuclear Waste. PNL-2481, Pacific Northwest Laboratory, Richland, Washington.

Scholes, S. R. 1975. Modern Glass Practice, CBI Publishing Company, Inc., Boston, Massachusetts. 


\section{BIBLIOGRAPHY}

Cable, M. 1966. "Kinetics and Mechanisms of Fining Glasses," J. Am. Ceramic Soc., $49: 436$.

Cable, M., and C. G. Rasul. 1967. "Spontaneous Bubble Formation in Silica Melts: II, Effects of Wet Atmospheres and Behavior of Mixed Alkali Glasses," J. Am. Ceramic Soc., 50:528.

Conroy, A. R., W. H. Manring, D. D. Billings and W. C. Bauer. 1963. "Controlled Atmosphere Hot-Stage for Microscopic Observation of Glass Melting Phenomena, Part II. Experimental Observations," The Glass Industry, March, Magazines for Industry, New York, New York.

Dannheim, H. and T. Frey. 1978. "Mossbauer Investigation of the Incorporation of Tin and Iron in Sodium Borate Glasses," Borate Glasses, Material Science Research, Vol. 12, pp. 227-238, Plenum Press, New York, New York.

Herring, A. P. and W. C. Bauer. 1980. "Electrolysis Reactions in Molten SodaLime Glass," Glass Technology, 21(2).

Johnston, W. D. 1964. "Oxidation-Reduction in Iron-Containing Glass," J. Am. Ceramic Soc., 47:198.

Lorey, L. D. 1966. "Re-boil Phenomena in Glass," Bullet in of Am. Ceramic Soc., 45:1012.

Manring, W. H. 1973. "Discussion on Influence of Furnace Atmosphere on the Melting-Fining Rate of Soda-Lime Glasses," Canadian Clay and Ceramics, February.

Manring, W. H. and R. E. Davis. 1978. "Controlling Redox Conditions in Glass Melting," The Glass Industry, May, Magazines for Industry, New York, New York.

Manring, W. H. et al. 1967. "Reduced Sulfur Compounds as Melting and Refining Aids for Flint Soda-L ime Glasses," The Glass Industry, July, Magazines for Industry, New York, New York.

Ohio State University. 1978. Collected Papers, 39th Annual Conference on Glass Problems, November 15 and 16, 1978, Department of Ceramic Engineering, Ohio State University, Columbus, Ohio.

Pye, L. D. 1980. Redox Behavior of Simulated Nuclear Waste Melts, New York State College of Ceramics, Alfred University, Alfred, New York.

Shaffer, E. W. "An Improved Technique for Measuring Reboil," Proceedings of 35th Annual Conference on Glass Problems, Department of Ceramics Engineering, Ohio State University, Columbus, Ohio.

Sutton, K. D. 1979. "Northwestern Completes Successful Electric Melting Application," Ceramic Industry, 113(5). 


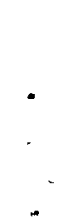




\section{APPENDIX}

This appendix contains $x$-ray spectra traces from the examination with the $x$-ray florescence microprobe of batch samples heated to the temperatures indicated for one hour. 


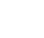

.

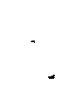




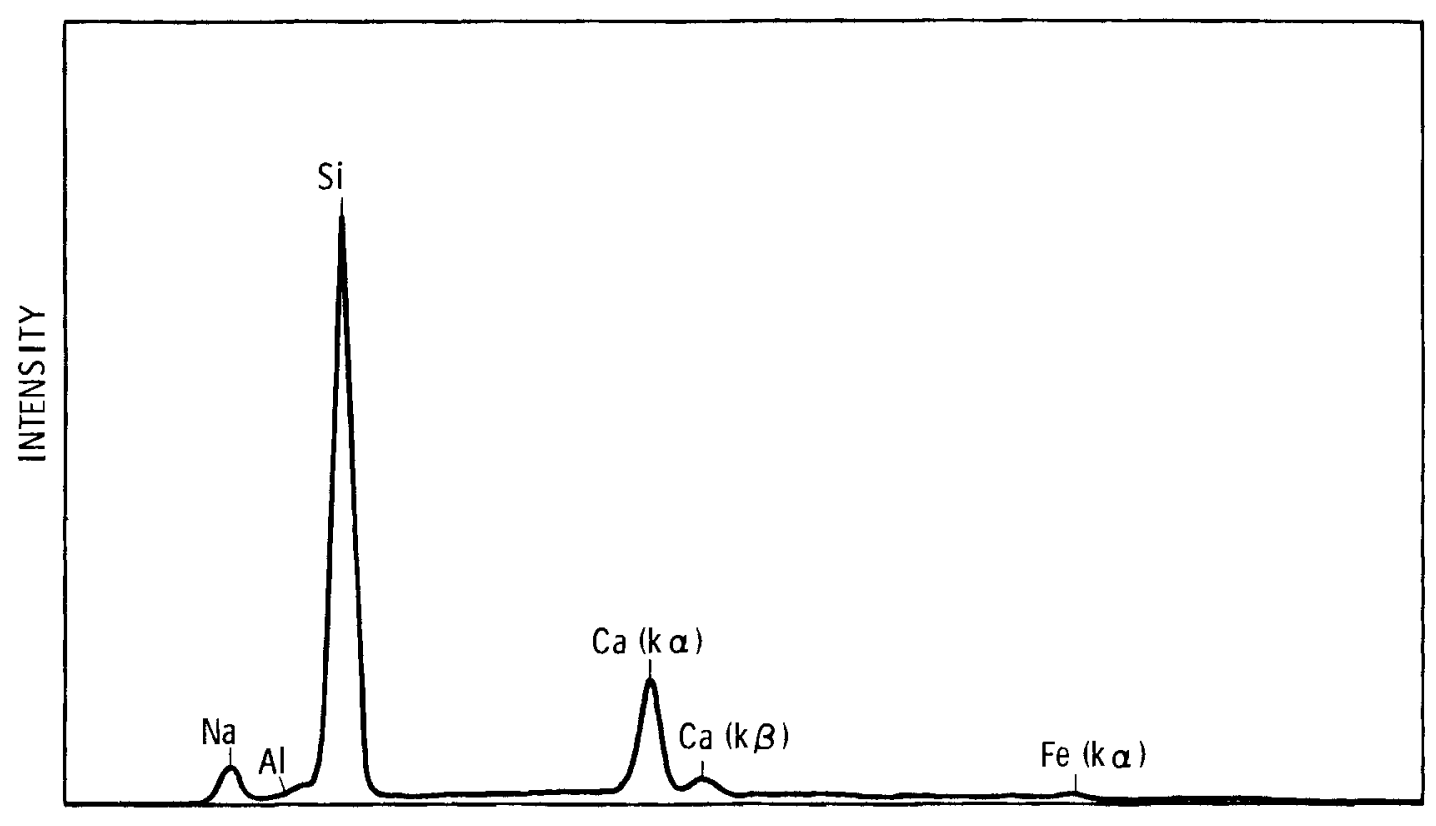

ENERGY

FIGURE A.1. X-ray Spectrum Trace of Particle-Free Matrix in Sample Held at $675^{\circ} \mathrm{C}$

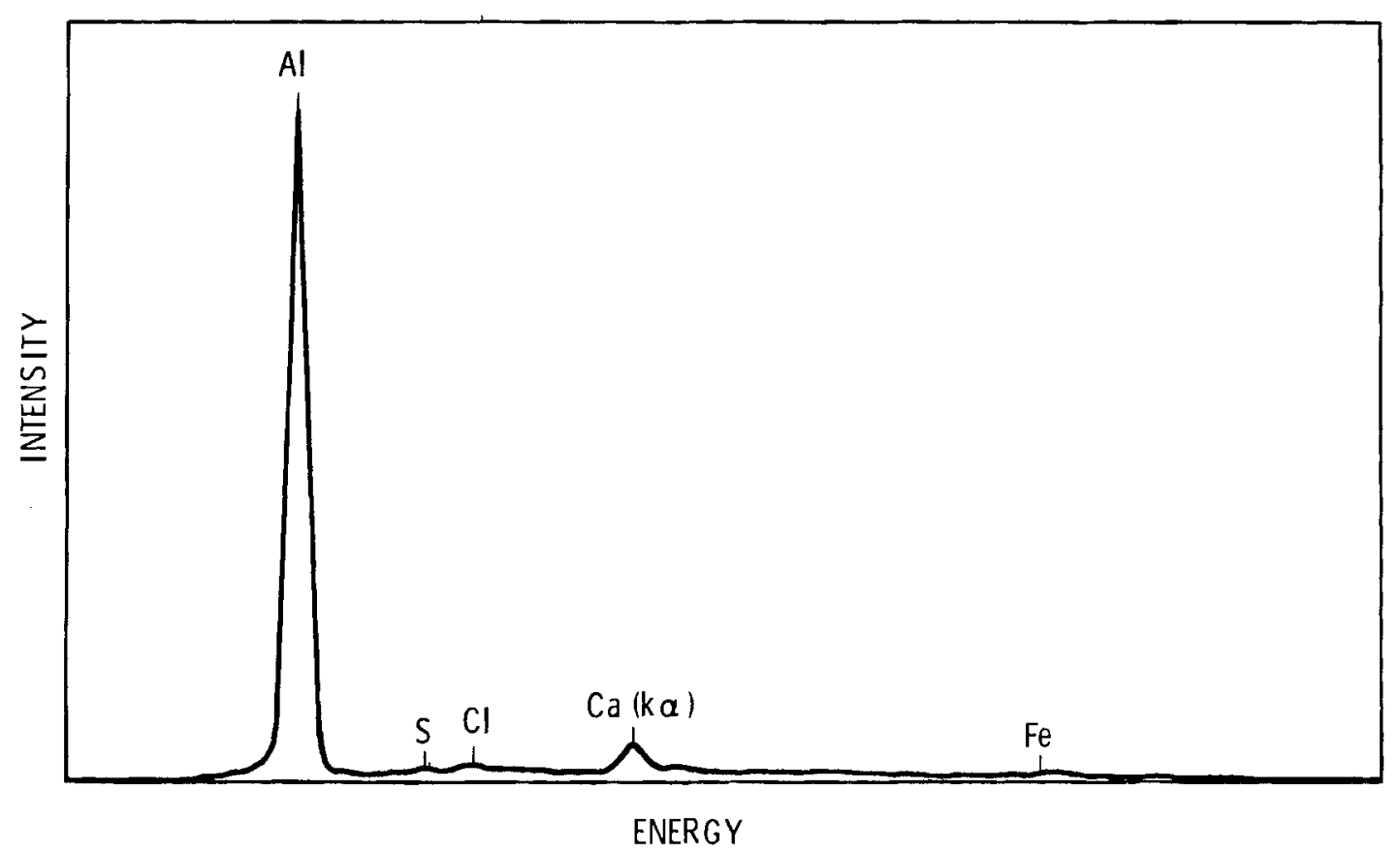

FIGURE A.2. X-ray Spectrum Trace of Second Matrix Phase in Sample Held at $675^{\circ} \mathrm{C}$ 


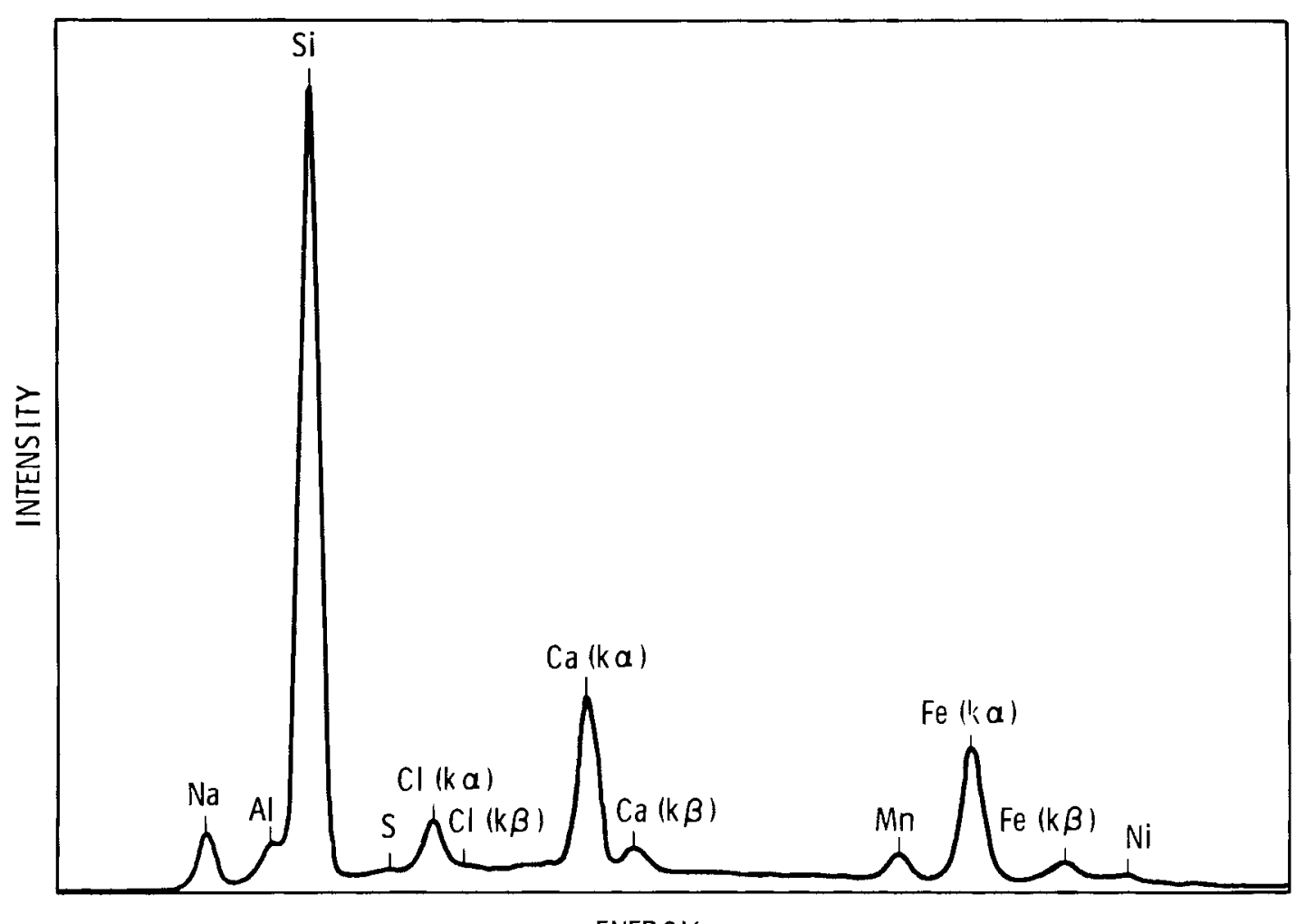

ENERGY

FIGURE A.3. X-ray Spectrum Trace of Continuous Matrix in Sample Held at $700^{\circ} \mathrm{C}$

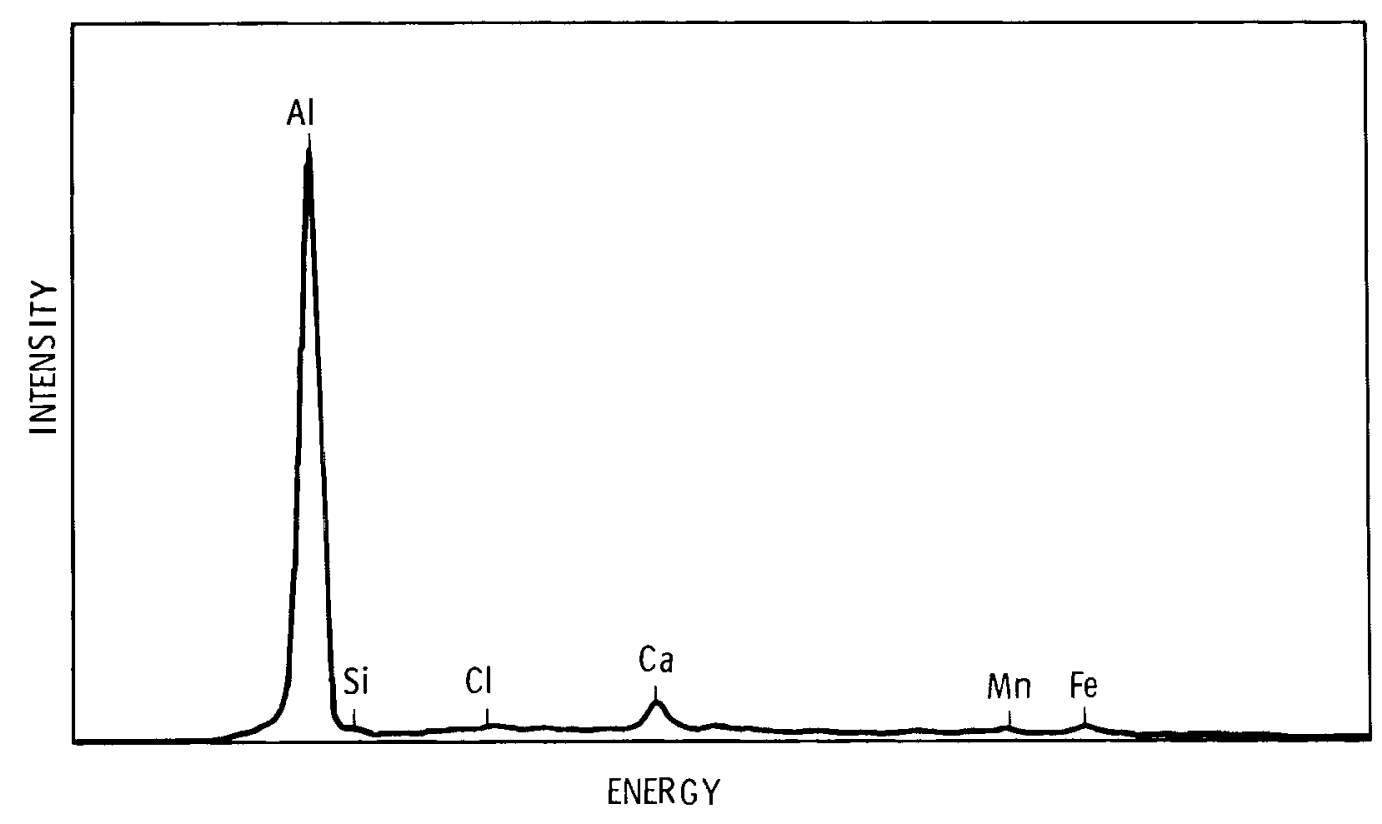

FIGURE A.4. X-ray Spectrum Trace of Second Matrix Phase in Sample Held at $700^{\circ} \mathrm{C}$ 


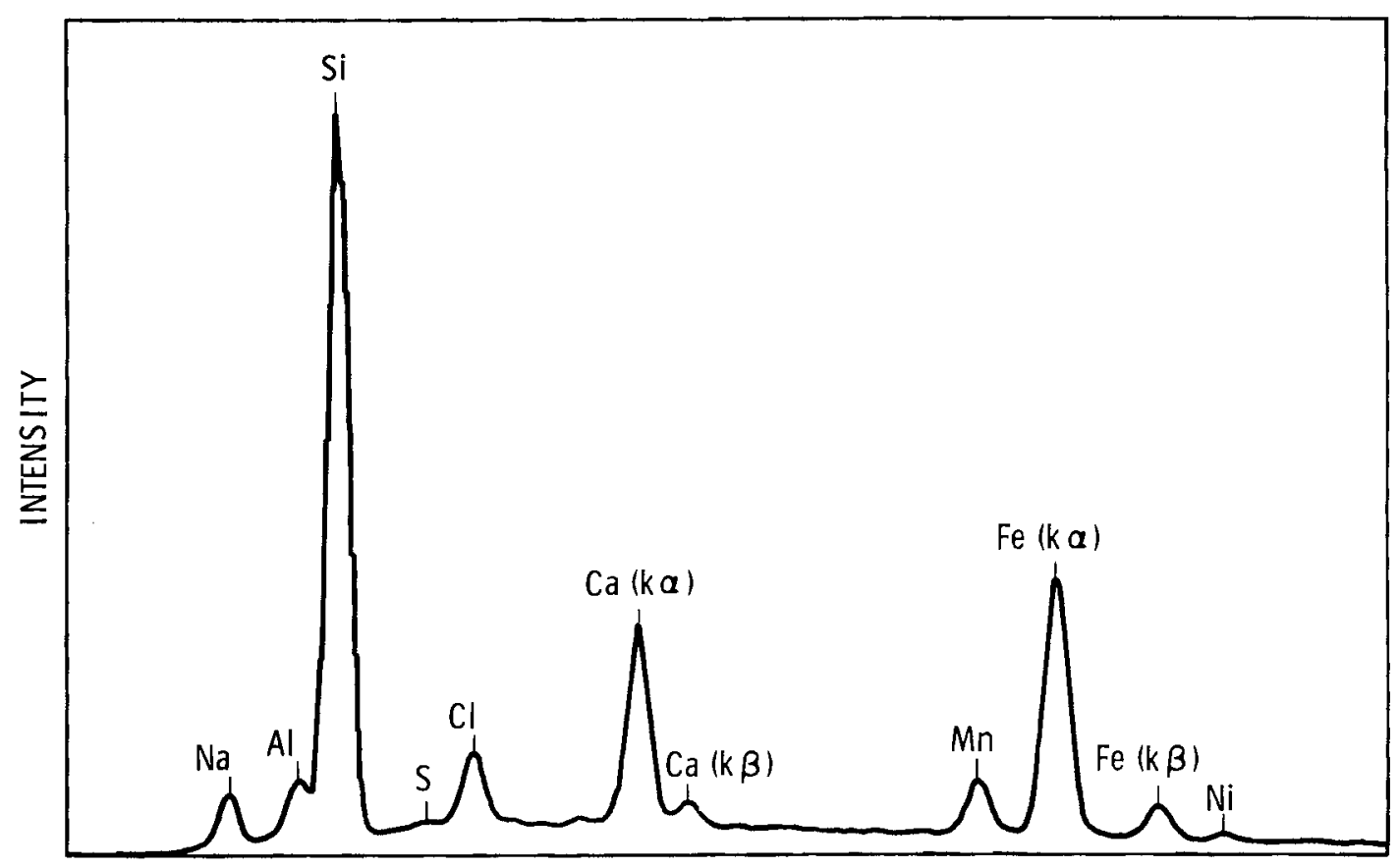

ENERGY

FIGURE A.5. X-ray Spectrum Trace of Continuous Matrix in Sample Held at $750^{\circ} \mathrm{C}$

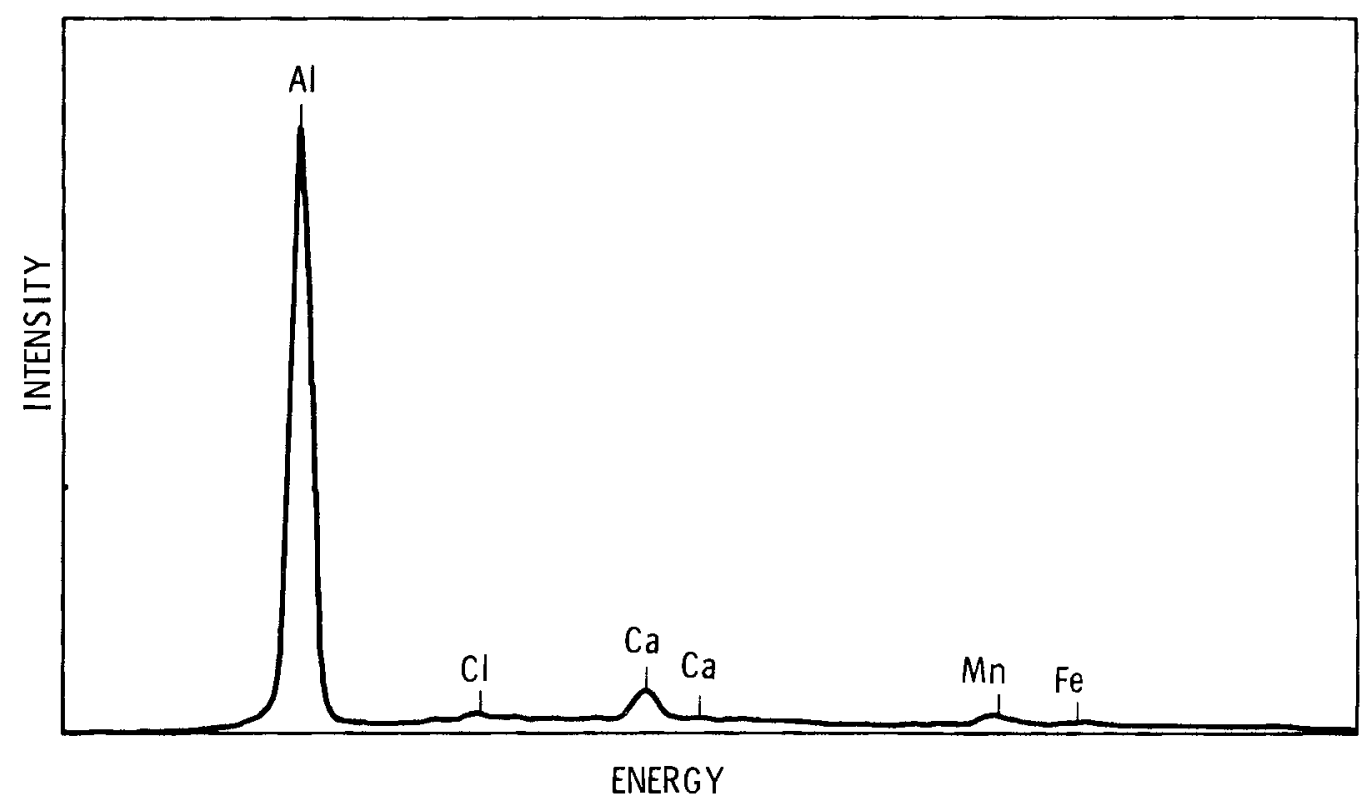

FIGURE A.6. X-ray Spectrum Trace of Second Matrix Phase in Sample Held at $750^{\circ} \mathrm{C}$ 


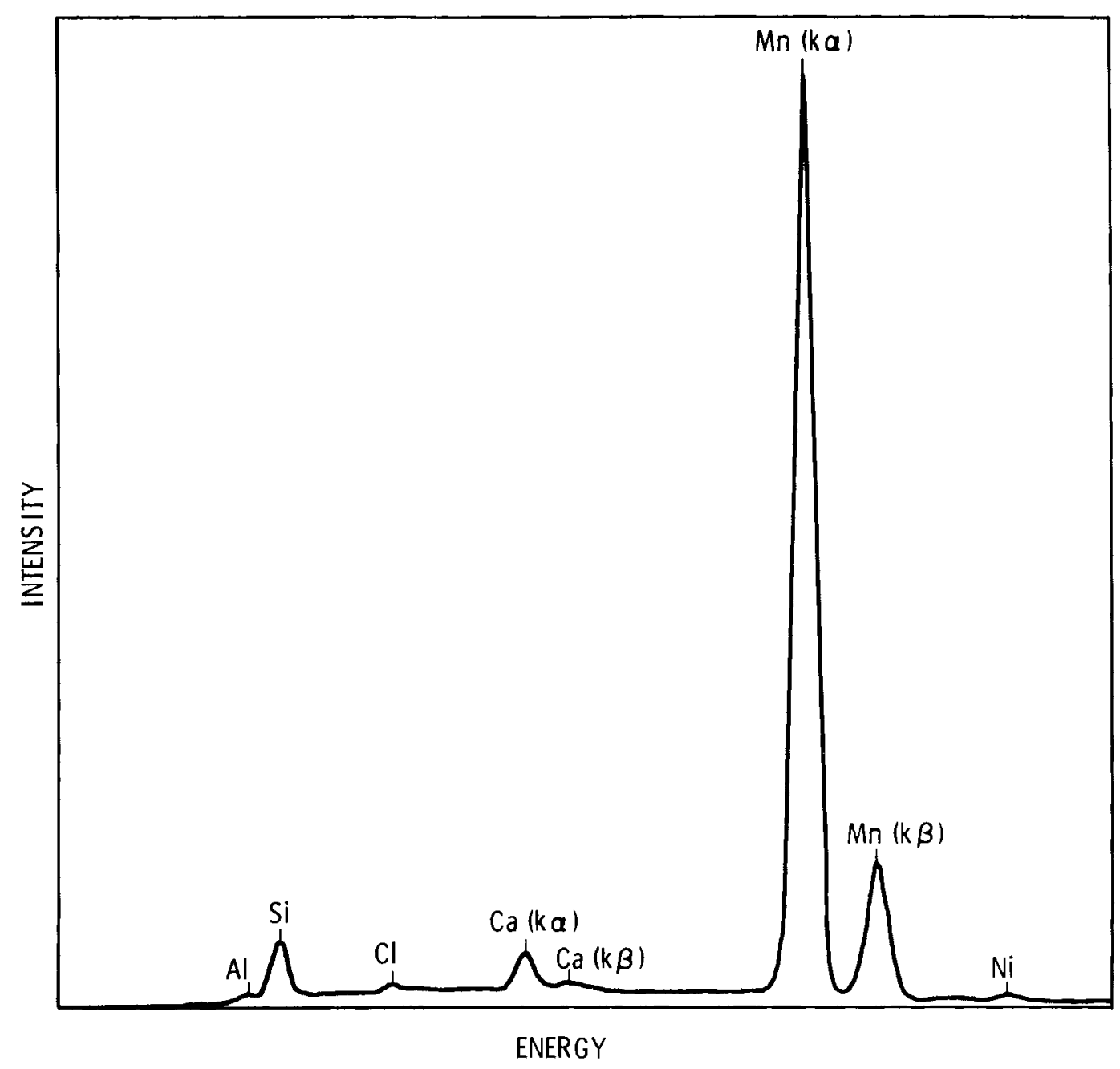

FIGURE A.7. X-ray Spectrum Trace of Large Particles in Sample Held at $750^{\circ} \mathrm{C}$ 


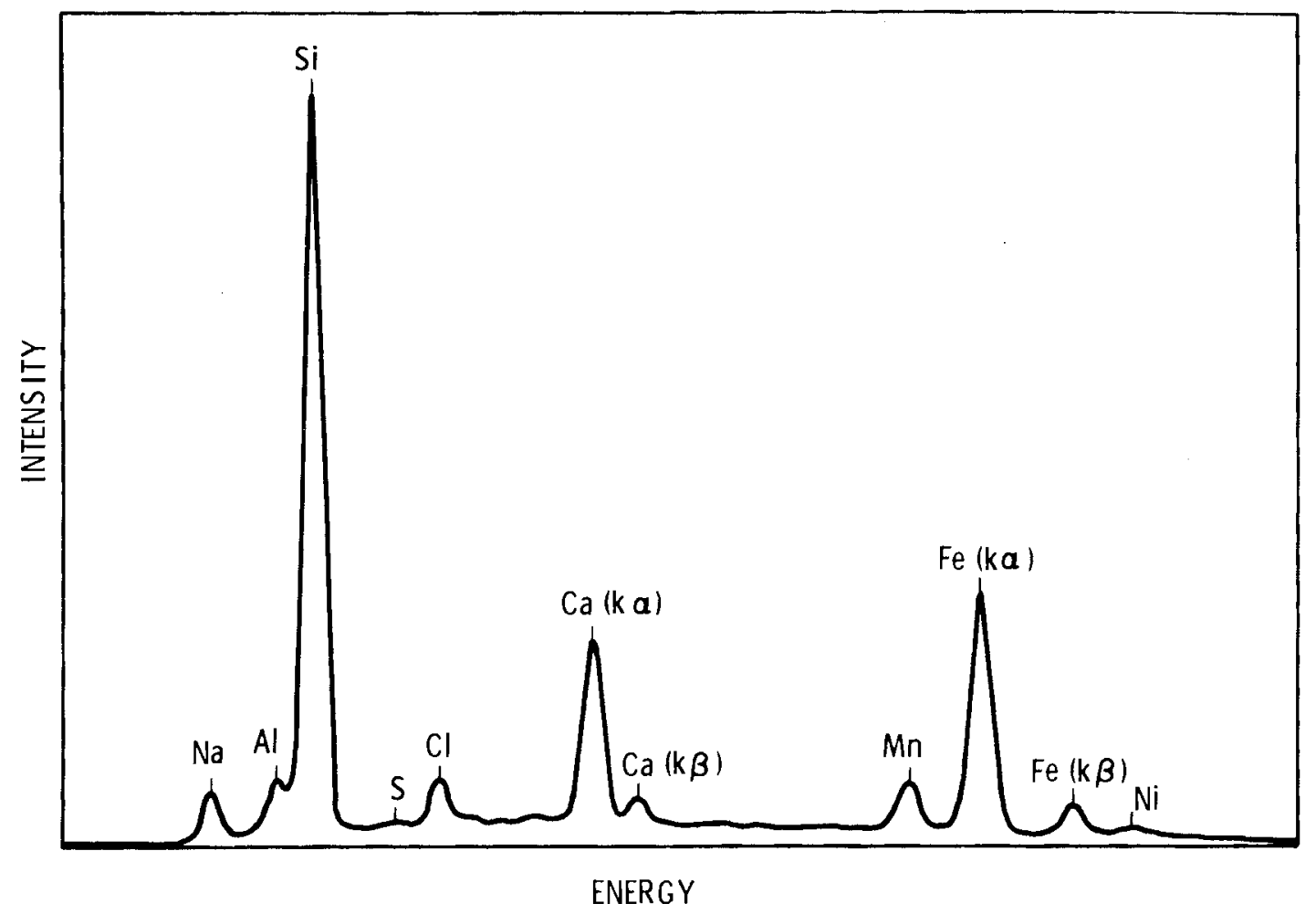

FIGURE A.8. X-ray Spectrum Trace of Continuous Matrix in Sample Held at $800^{\circ} \mathrm{C}$

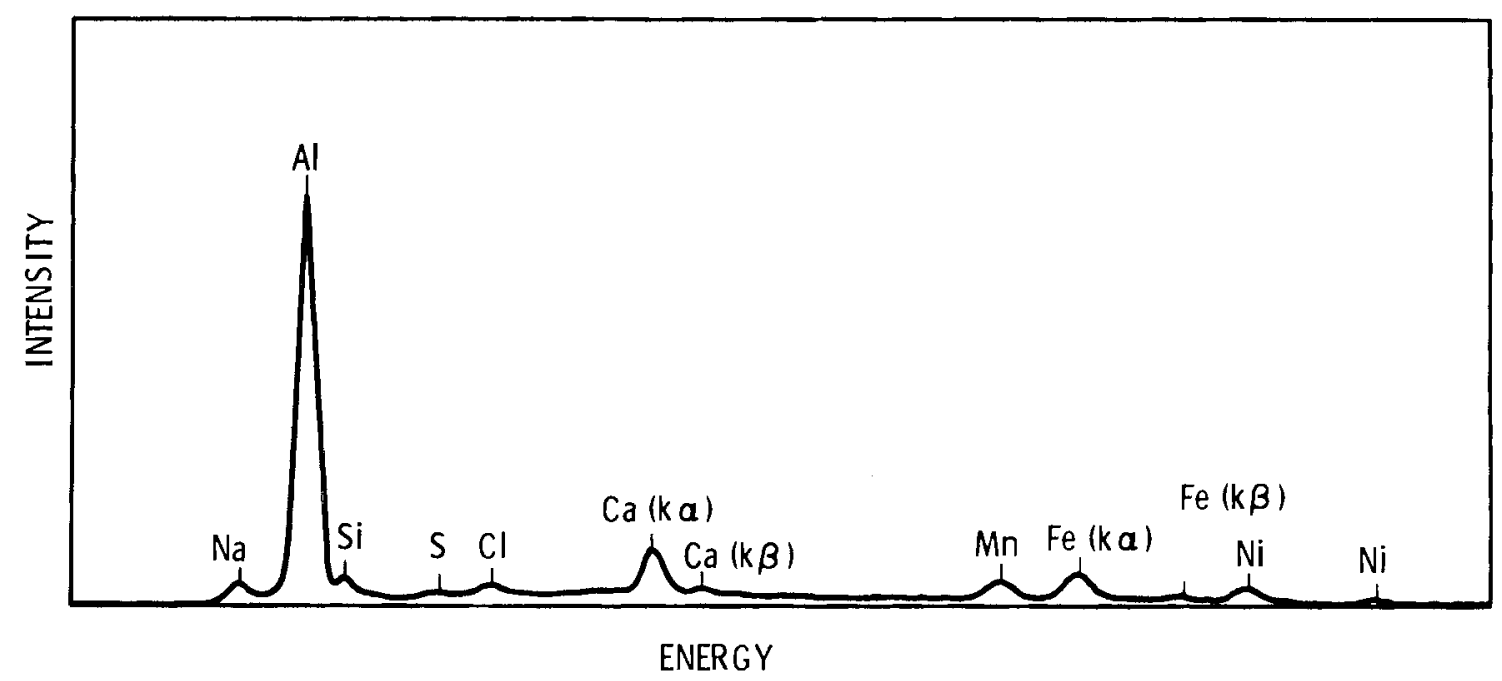

FIGURE A.9. X-ray Spectrum Trace of Second Matrix Phase in Sample Held at $800^{\circ} \mathrm{C}$ 

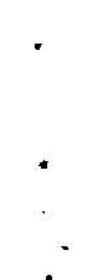


\section{DISTRIBUTION}

No. of

Copies

OFFSITE

A. A. Churm

DOE Chicago Patent Group

9800 South Cass Avenue

Argonne, IL 60439

R. Y. Lowrey

DOE Albuquerque Operations Office

P. 0. Box 5400

Albuquerque, NM 87185

A. L. Taboas

DOE Albuquerque Operations Office

P. 0. Box 5400

Albuquerque, NM 87185

S. A. Mann

DOE Chicago Operations and Region Office

Argonne, IL 60439

J. Neff

Department of Energy

Columbus Program office

$505 \mathrm{~K}$ ing Avenue

Columbus, $\mathrm{OH} 43201$

W. E. Mott

DOE Division of Environmental

Control Technology

Washington, DC 20545

J. P. Hamric

DOE I daho Operations Office

550 2nd St.

Idaho Falls, ID 38401

J. W. Peel

DOE Idaho Operations Office

550 2nd St.

Idaho Falls, ID 38401
No. of

Copies

J. B. Whitsett

DOE Idaho Operations Office

550 2nd St.

Idaho Falls, ID 38401

C. R. Cooley

DOE Nuclear Waste Management Programs

NEW, B-107, HQ

Washington, DC 20545

G. H. Daly

DOE Nuclear Waste Management Programs

NEW, B-107, HQ

Washington, DC 20545

J. E. Dieckhoner

DOE Nuclear Waste Management Programs

NEW, B-107, HQ

Washington, DC 20545

C. H. George

DOE Nuclear Waste Management Programs

NEW, B-107, HQ

Washington, DC 20545

C. A. Heath

DOE Nuclear Waste Management Programs

NEW, B-107, HQ

Washington, DC 20545

M. L. Lawrence

DOE Nuclear Waste Management Programs

NEW, B-107, HQ

Washington, DC 20545

D. J. McGoff

DOE Nuclear Waste Management Programs

NEW, B-107, HQ

Washington, DC 20545 
No. of

Copies

S. Meyers/R. Romatowski

DOE Nuclear Waste Management Programs

NEW, B-107, HQ

Washington, DC 20545

G. 0ertel

DOE Nuclear Waste Management Programs

NEW, B-107, HQ

Washington, DC 20545

A. F. Perge

DOE Nuclear Waste Management Programs

NEW, B-107, HQ

Washington, DC 20545

R. W. Ramsey, Jr.

DOE Nuclear Waste Management Programs

NEW, B-107, HQ

Washington, DC 20545

D. L. Vieth

DOE Nuclear Waste Management Programs

NEW, B-107, HQ

Washington, DC 20545

R. D. Walton

DOE Nuclear Waste Management Programs

NEW, B-107, HQ

Washington, DC 20545

S. W. Ahrends

DOE Oak Ridge Operations Office

P. 0. Box E

Oak Ridge, TN 37830

D. Large

DOE Oak Ridge Operations Office P. 0. Box E

Oak Ridge, TN 37830
No. of

Copies

S. G. Harbinson

DOE San Francisco Operations Office

1333 Broadway

0akland, CA 94612

E. S. Goldberg

DOE Savannah River Operations Office

P. 0. Box A

Aiken, SC 29801

T. B. Hindman

DOE Savannah River Operations Office

P. 0. Box A

Aiken, SC 29801

R. P. Whitfield

DOE Savannah River Operations Office

P. 0. Box A

Aiken, SC 29801

Los Alamos Scientific Laboratory

P. 0. Box 1663

Los Alamos NM 87544

J. B. Martin

Division of Waste Management

Nuclear Regulatory Commission

Washington, DC 20555

D. M. Rohrer

Division of Waste Management

Nuclear Regulatory Commission

Washington, DC 20555

R. Dale Smith

Division of Waste Management

Nuclear Regulatory Commission

Washington, DC 20555

R. E. Cunningham

Office of Nuclear Safety

Materials and Safeguards

Nuclear Regulatory Commission

Room 562, 7915 Eastern Avenue

Silver Springs, MD 20910 
No. of

Copies

27 DOE Technical Information Center

J. A. Buckham

Allied-General Nuclear Services

P. 0. Box 847

Barnwell, SC 29812

A. Williams

Allied-General Nuclear Services

P. 0. Box 847

Barnwe11, SC 29812

J. W. Bartlett

The Analytical Sciences Corp.

6 Jacob Way

Reading, MA 01867

J. H. Kittel

Argonne National Laboratory

9700 South Cass Avenue

Argonne, IL 60439

M. J. Steindler/L. E. Trevorrow Argonne National Laboratory 9700 South Cass Avenue

Argonne, IL 60439

A. Brandstetter

Battelle Memorial Institute

Office of Nuclear Waste

Isolation

505 King Avenue

Columbus, $\mathrm{OH} 43201$

W. Carbiener

Battelle Memorial Institute

Office of Nuclear Waste

Isolation

505 King Avenue

Columbus, $\mathrm{OH} 43201$

N. E. Carter

Battelle Memorial Institute

Office of Nuclear Waste

I solation

505 King Avenue

Columbus, $\mathrm{OH} 43201$
No. of

Copies

P. L. Hofmann

Battelle Memorial Institute

Office of Nuclear Waste

Isol ation

505 King Avenue

Columbus, $\mathrm{OH} 43201$

M. Kehnemuyi

Battelle Memorial Institute

Office of Nuclear Waste

Isolation

505 King Avenue

Columbus, $\mathrm{OH} 43201$

Bever ly Rawles

Battelle Memorial Institute

Office of Nuclear Waste

Isolation

505 King Avenue

Columbus, $\mathrm{OH} 43201$

R. Maher, Program Manager

Waste Management Programs

Savannah River Plant

E. I. Du Pont de Nemours \& Co.

Aiken, SC 29801

W. H. Baker

E. I. Du Pont de Nemours \& Co.

Savannah River Laboratory

Aiken, SC 29801

J. L. Cranda 11

E. I. Du Pont de Nemours \& Co.

Savannah River Laboratory

Aiken, SC 29801

R. G. Garvin

E. I. Du Pont de Nemours \& Co.

Savannah River Laboratory

Aiken, SC 29801

L. W. Meyer

E. I. Du Pont de Nemours \& Co.

Savannah River Laboratory

Aiken, SC 29801 
No. of

Copies

S. Mirshak

E. I. Du Pont de Nemours \& Co. Savannah River Laboratory

Aiken, SC 29801

J. A. Porter

E. I. Du Pont de Nemours \& Co. Savannah River Laboratory

Aiken, SC 29801

G. B. Levin

$E G$ \& G I daho

P. 0. Box 1625

Idaho Falls, ID 83415

R. Williams

Electric Power Research Institute

3412 Hillview Avenue

P. 0. Box 10412

Palo Alto, CA 94304

J. L. Larocca, Chairman

Engineering Research and Development Authority

Empire State Plaza

Albany, NY 12223

Environmental Protection Agency

Technological Assessment

Division (AW-559)

Office of Radiation Programs

U.S. Environmental Protection Agency

Washington, DC 20460

W. F. Holcomb

Office of Radiation Programs

(A-460)

U. S. Environmental Protection Agency

Washington, DC 20460
No. of

Copies

D. M. Rosenbaum

Office of Radiation Programs

U.S. Environmental Protection Agency

1921 Jefferson Davis Highway

Arlington, VA 22202

R. A. Brown

Exxon Nuclear Idaho

P. 0. Box 2800

Idaho Falls, ID 83401

G. L. Ritter

Exxon Nuclear Idaho

P. 0. Box 2800

Idaho Falls, ID 83401

T. R. Thomas

Exxon Nuclear Idaho

P. 0. Box 2800

Idaho Falls, ID 83401

File Copy

Exxon Nuclear Idaho

P. 0. Box 2800

Idaho Falls, ID 83401

G. E. Benedict

General Atomics Co.

P. 0. Box 81608

San Diego, CA 92138

L. H. Brooks

Gulf Energy and Environmental Systems

P. 0. Box 81608

San Diego, CA 92138

J. D. Tewhey

Lawrence Livermore Laboratory

P. 0. Box 808

Livermore, CA 94550

R. Roy

202 Materials Research Laboratory

Pennsylvania State University

University Park, PA 16802 
No. of

Copies

C. J. Kershner

Mons anto Research Corporation

Mound Laboratory

P. 0. Box 32

Miamisburg, $\mathrm{OH} 45342$

J. P. Duckworth

$P$ lant Manager

Nuclear Fuels Services, Inc.

P. 0. Box 124

West Valley, NY 14171

R. E. Blanco

Oak Ridge National Laboratory

P. 0. Box $Y$

Oak Ridge, TN 37830

J. 0. Blomeke

0 ak Ridge National Laboratory

P. 0. Box Y

Oak Ridge, TN 37830

D. E. Ferguson

Oak Ridge National Laboratory P. 0. Box Y

Oak Ridge, TN 37830

A. L. Lotts

Oak Ridge National Laboratory

P. 0. Box X

Oak Ridge, TN 37830

R. S. Lowrie

Oak Ridge National Laboratory

P. 0. Box Y

Oak Ridge, TN 37830

A. B. Martin

Rockwell International

8900 DeSoto Avenue

Canoga Park, CA 91304

H. Recht

Dept. 737-710

Atomics International Division

Rockwell International

Box 309

Canoga Park, CA 91304
No. of

Copies

W. S. Bennett

Rockwell International

Rocky Flats Plant

P. 0. Box 464

Golden, C0 80401

Lawrence J. Smith

Rockwell International

Rocky Flats Plant

P. 0. Box 464

Golden, CO 80401

E. Vejvoda

Rockwell International

Rocky Flats Plant

P. 0. Box 464

Golden, CO 80401

D. R. Anderson

Sand ia Laboratories

Albuquerque, NM 87185

0 . E. Jones

Sandia Laboratories

Albuquerque, NM 87185

R. G. Kepler

Sand ia Laboratories

Albuquerque, NM 87185

W. Weart

Sandia Laboratories

Albuquerque, NM 87185

D. E. Harrison

West inghouse Electric Corp.

P. 0. Box 10864

Pittsburgh, PA 15236

P. Macedo

Vitreous State Laboratory

Catholic University of America

Washington, DC 20064

R. G. Post

College of Engineering

University of Arizona

Tucson, AZ 85721 
No. of

Copies

L. L. Hench

Dept. of Materials Science and Engineering

University of Florida

Gainesville, FL 32611

Dr. Hayne Palmour III

ERSD 17517

North Carolina State University

P. 0. Box 5995

Raleigh, NC 27650

F. K. Pittman

3508 Sagecrest Terrace

Ft. Worth, TX 76109

\section{ONSITE}

7 DOE Richland Operations Office

E. A. Bracken

P. A. Craig

R. E. Gerton

H. E. Ransom

J. J. Schreiber

M. W. Shupe

M. J. Zamorsk i

11 Rockwe 11 Hanford Operations

H. Babad

L. C. Brown

R. A. Deju

R. J. Gimera

D. R. Gustavson

E. J. Kosiancic

C. M. Manry

I. E. Reep

J. H. Roecker

D. D. Wodrich

File Copy

UNC United Nuclear Industries

T. E. Dabrowski

2 Westinghouse Hanford Company
No. of

Copies

71 Pac if ic Northwest Laboratory

S. M. Barnes

W. J. Bjork lund

H. T. Blair (20)

W. F. Bonner

R. A. Brouns

J. L. Buelt

L. A. Chick

T. D. Chikalla

C. M. Devary

R. D. Dierks

M. S. Hanson

A. J. Haverfield

M. H. Henry

L. K. Holton

J. H. Jarrett

D. E. Knowlton

C. A. Knox

W. L. Kuhn

D. E. Larson

G. B. Long

J. M. Lukacs

S. A. McCullough (3)

J. L. McElroy

G. B. Mellinger

J. E. Mende 1

F. A. Miller

R. D. Nelson

R. E. Nightingale

K. H. Oma

C. R. Palmer

P. J. Pelto

A. M. Platt

D. L. Prezbindowski (2)

W. A. Ross

J. M. Rusin

D. H. Siemens

F. A. Simonen

S. C. Slate

C. L. Timmerman

R. L. Treat

R. P. Turcotte

R. E. Westerman

Technical Information (5)

Publishing Coordination $\mathrm{Vi}$ (2)

A. G. Blasewitz

G. L. Richardson 